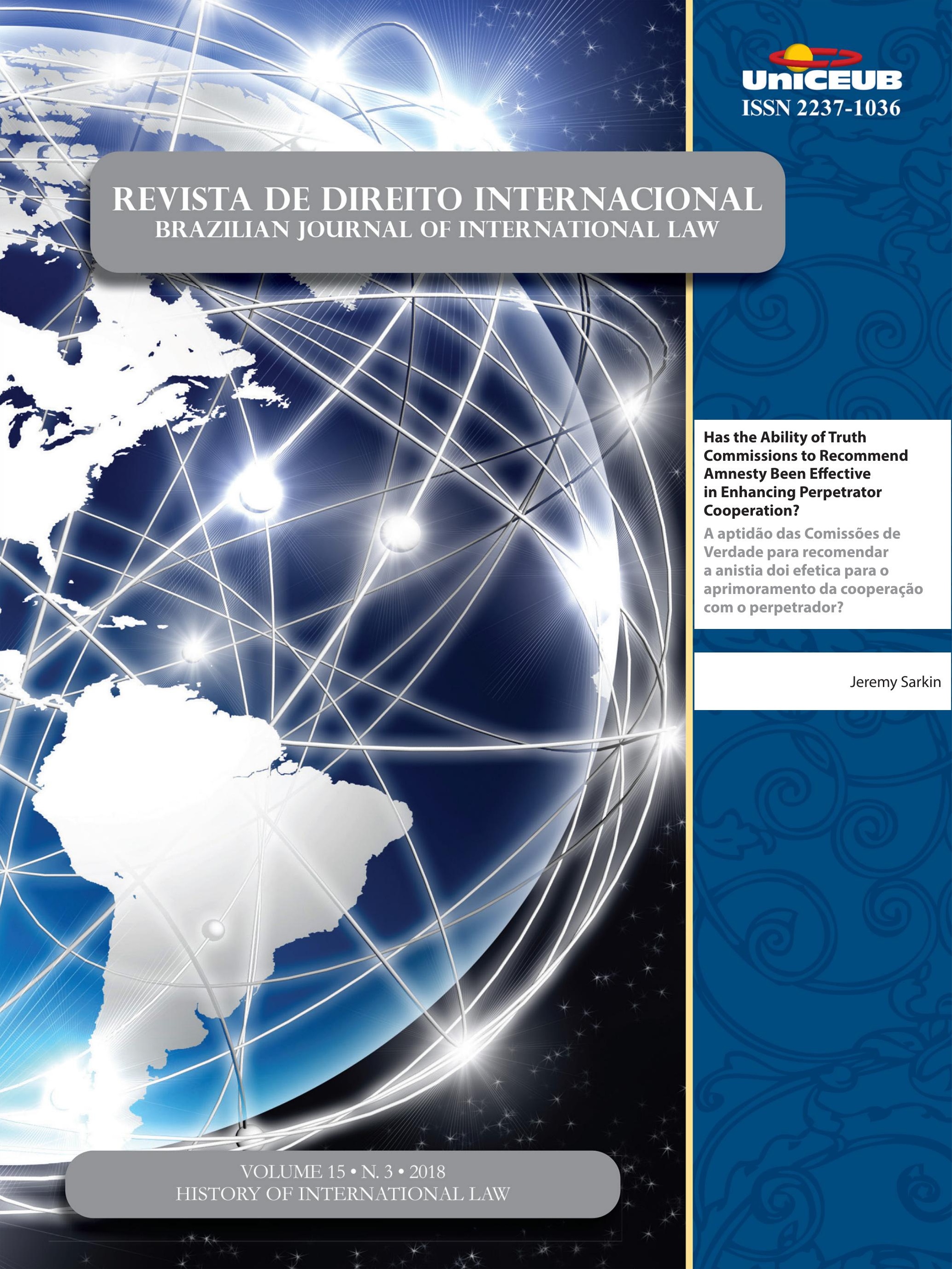




\section{Sumário}

I. Dossiê Especial: History of International Law ...................................1

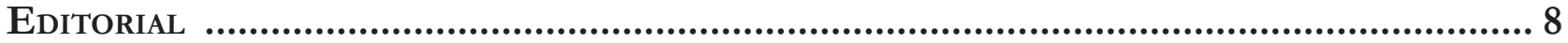

What does it mean to apply history in international law studies? ....................................................... 8

Arthur Roberto Capella Giannattasio

SuR LA NATURE DU Droit ISLAMIQUe............................................................................14

Hocine Benkheira

Islamic Shari’a Law, History and Modernity: Some Reflections .................................25 Suleiman A. Mourad

The (Un)practical Secularization Process: International Law and Religion as So-

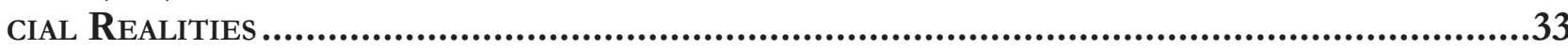

Douglas de Castro

BRAZILIAN LITERATURE ON INTERNATIONAL LAW DURING THE EMPIRE REGIME. OR THE DIFFUSION OF INTERNATIONAL LAW IN THE PERIPHERIES THROUGH APPROPRIATION AND ADAPTATION.

Airton Ribeiro da Silva Júnior

Natural, POSitivo, romano E Universal? INVESTigaÇão SObre O Direito das GENTES EM

Tomás de Aquino

Rafael Zelesco Barretto

II. Artigos sobre outros temas

VINCULAÇÃO DOS DIREITOS ECONÔMICOS, SOCIAIS E CULTURAIS: UMA DISCUSSÃO DO DESENVOLVImento humano com base no conceito de Amartya Sen sobre o mínimo existencial.....99

Natalia Mascarenhas Simões Bentes e Yasmim Salgado Santa Brígida

A NOVA LeI de MigraÇão E A PROTEÇão CONFERIDA AO APÁtrida: ALINHAMENTO BRASILEIRO AO PADRÃO INTERNACIONAL DE DIREITOS HUMANOS

Pedro Henrique de Faria Barbosa e Sylvio Loreto

E se o Supremo Tribunal Federal (STF) restabelecer a vigência da Convenção n. 158 
da Organização Internacional do Trabalho (OIT) na ordem Jurídica brasileira? SoBRE UMA POSSÍVEL REVIRAVOLTA, PELA VIA DO DIREITO INTERNACIONAL, DAS LEIS TRABALHISTAS BRASILEIRAS 138

Daniel Damasio Borges

JULGADOS DA CORTE INTERAMERICANA SOBRE CASOS BRASILEIROS E POLÍTICAS PÚBLICAS: REFLEXÕES ACERCA DE POSSÍVEIS INFLUIÇÕES 165

Rafael Osvaldo Machado Moura

CREATING BRIDGES BETWEEN INTERNATIONAL RELATIONS THEORY AND INTERNATIONAL HUMAN RIGHTS LAW: CONSTRUCTIVISM AND THE ROLE OF BRAZIL IN THE INTER-AMERICAN SYSTEM OF HUMAN RIGHTS 179

Ismael Francisco de Souza, Luciana Rocha Leme e Erick da Luz Scherf

Justiça de transição na Argentina e o Sistema Interamericano de Direitos Humanos: uMa ANÁlise do CASo Luis Muiña (“REgRa 2x1”) 199

Emilio Peluso Neder Meyer e Jessica Holl

A legalidade e legitimidade da INTERVEnÇão humanitÁria: UMA MEDIDA AINDA NECESSÁRIa.219 Natália Caye Batalha Boeira

O Acordo de Escazú E o ACESSo À INFORMaÇão AMbiental no Brasil. 252 Érica Bezerra Queiroz Ribeiro e Bruno Amaral Machado

Dos POVOS NATIVOS AO SURGIMENTO DOS MOVIMENTOS SOCIAIS: INFLUÊNCIAS DOS DISCURSOS JURÍDICOS, RELIGIOSOS E MÉDICOS PARA A CONSTRUÇÃO DO CONCEITO DE HOMOSSEXUALIDADE NO BRASIL .267 Bruno Rafael Silva Nogueira Barbosa e Robson Antão de Medeiros

Aspectos Jurídicos da PARTicipaÇão dA UNião Europeia NA OMC: COMPREENDENdo SUTILEZAS DE UM DELICADO ENLACE. 291

Camilla Capucio

Path to judicial activism? The use of "Relevant rules of international law" by the WTO Appellate Body

Mariana Clara de Andrade

LEVEZA E PESO NA MEDIAÇÃO COMERCIAL INTERNACIONAL: O CONTEÚDO JURÍDICO DO ACORDO CORPORATIVO MEDIADO E SUA INCORPORAÇÃo PELO DiREITO BRASILEIRO .324 Henrique Lenon Farias Guedes 
JURISDIÇÃO INTERNACIONAL E AS DIFICULDADES DE EXECUÇÃO DE SENTENÇAS INTERNACIONAIS NO BRASIL

Nevitton Vieira Souza

O DEVER DE COOPERAÇÃo NOS CONTRATOS DE VENDA INTERNACIONAL DE MERCADORIAS: PRESSUPOSTOS TEÓRICOS E REPERCUSSÕES PRÁTICAS DA CLÁUSULA GERAL DA BOA-FÉ OBJETIVA PARA A APLICAÇÃo DA CISG .358

Angelo Gamba Prata de Carvalho

A DiMENSÃo JURÍdiCA DO IMPERIALISMO NA (DES)ORDEM GLOBAL CAPITALISTA: UMA ANÁLISE COM BASE NA CRÍTICA MARXISTA AO DIREITO INTERNACIONAL E ÀS RELAÇÕES POLÍTICO-ECONÔMICAS DE DOMINAÇÃO E DEPENDÊNCIA.

Thomaz Delgado De David, Maria Beatriz Oliveira da Silva e Rosane Beatris Mariano da Rocha Barcellos Terra

A participaÇão de Brasil e Estados Unidos na formulação das regras multilaterais do

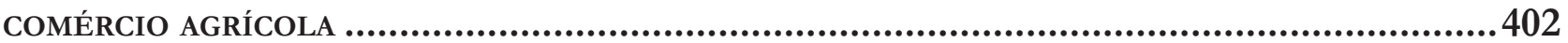

Vera Thorstensen, Vivian Daniele Rocha Gabriel e Alebe Linhares Mesquita

A galáxia lex e a construÇão de um Sistema jurídico transnacional ........................ 441

Eugênia Cristina Nilsen Ribeiro Barza e Jéssyka Maria Nunes Galvão

Has the Ability of Truth Commissions to Recommend Amnesty Been Effective in Enhancing Perpetrator Cooperation? 453 Jeremy Sarkin

A CONCEPTUAL PAPER ON THE POLICY-FRAMEWORK THAT MIRRORS THE DYNAMIC LINK BETWEEN Human Security, Social Protection and Safety Nets, and Food and Nutritional Security: The Case of the "Gulayan sa Paaralan Program", the Philippines.... 478 Renato Lagapa Base

INCENTIVISING SMALLHOLDER FARMER LIVELIHOODS AND CONSTRUCTING FOOD SECURITY THROUGH HOME-GROWN SCHOOL FEEDING: EVIDENCE FROM NORTHERN GHANA .491

Clement Mensah

Policy COHERENCE In THE IMPLEMENTATION OF THE 2030 AgENDA FOR SUSTAINABLE DEVELOpment: the Brazilian School Feeding Programme Case Study .506 Mariana Werlang Girardi 


\title{
Has the Ability of Truth Commissions to Recommend Amnesty Been Effective in Enhancing Perpetrator Cooperation? *
}

\author{
A aptidão das Comissões de Verdade para \\ recomendar a anistia doi efetica para o \\ aprimoramento da cooperação com o \\ perpetrador?
}

Jeremy Sarkin**

\section{Abstract}

This article examines the amnesty powers granted to a variety of truth commissions (TC). It considers whether the process by which TCs are able to recommend for perpetrators who cooperate with TCs (and usually provide truth) has ensured that such individuals come forward and cooperate with these institutions. This is decisive, as TCs everywhere experience difficulties in obtaining perpetrator cooperation and testimony. Crucially, unlike the South African TC, which had the power to directly grant amnesty, later TCs have only been able to recommend, to their governments, that amnesty be granted to specific persons who meet criteria laid out in the specific TC's legal mandate. The article therefore examines the efficacy of TC amnesty powers in South Africa, Grenada, Indonesia, the Democratic Republic of the Congo (DRC), Nepal, Timor-Leste/Indonesia, Liberia, Kenya, South Korea, and Timor-Leste. All these institutions had different provisions as to when, and for what reasons they could make a recommendation that amnesty be given (besides the South African TC which could directly grant amnesty). This article touches on some of the problems that may occur during such processes that need careful attention to ensure that perpetrators enter such conditional amnesty processes, and tell the truth once they do. The lessons learnt from the various TC amnesty processes are brought to the fore to determine what future TCs ought to bear in mind should it be decided to use conditional amnesty methods.

Keywords: Transitional Justice, truth commissions, truth, amnesty, conditional amnesty, immunity, pardons, perpetrator, search and seizure, South Africa, Grenada, Indonesia, the Democratic Republic of the Congo, TimorLeste, Indonesia, Liberia, Kenya, and South Korea.

** BA LLB (Natal) LLM (Harvard) LLD (UWC). Distinguished Visiting Professor of Law, and member of CEDIS, NOVA University, Lisbon, Portugal. He is admitted to practice as an Attorney in South Africa and an Attorney in New York, USA. He is a former ChairRapporteur, United Nations Working Group on Enforced or Involuntary Disappearances. I wish to express my appreciation to Robert Grant for his assistance on this article. E-mail : jeremy.sarkin@ymail.com

\section{Resumo}

Este artigo examina os poderes de anistia concedidos a uma variedade de comissões da verdade (TC). Ele considera se o processo pelo qual os TCs podem recomendar aos perpetradores que cooperam com os TCs (e ge- 
ralmente fornecem verdades) assegurou que tais indivíduos se apresentem e cooperem com essas instituições. Isso é decisivo, pois as TCs em todos os lugares enfrentam dificuldades para obter a cooperação e o testemunho do perpetrador. Crucialmente, diferentemente da TC Sul-Africana, que tinha o poder de conceder anistia diretamente, os TCs posteriores só puderam recomendar aos seus governos que a anistia fosse concedida às pessoas específicas que atendessem aos critérios estabelecidos no mandato legal da TC. O artigo examina a eficácia dos poderes de anistia da TC na África do Sul, Granada, Indonésia, República Democrática do Congo (RDC), Nepal, Timor-Leste / Indonésia, Libéria, Quênia, Coréia do Sul e Timor-Leste. Todas essas instituições tinham disposições diferentes sobre quando e por quais motivos poderiam fazer uma recomendação de anistia (além do TC sul-africano que poderia conceder anistia diretamente). Este artigo aborda alguns dos problemas que podem ocorrer durante esses processos, que requerem cuidadosa atenção para garantir que os autores entrem em tais processos de anistia condicional e digam a verdade quando o fizerem. As lições aprendidas com os vários processos de anistia da TC são trazidas à tona para determinar o que os futuros TCs devem ter em mente caso seja decidido usar métodos condicionais de anistia.

Palavras-chave : Justiça Transicional, comissões da verdade, verdade, anistia, anistia condicional, imunidade, perdão, perpetrador, busca e apreensão, África do Sul, Granada, Indonésia, República Democrática do Congo, Timor-Leste, Indonésia, Libéria, Quênia e Coréia do Sul .

\section{INTRODUCTION}

The role and function of truth commissions (TCs) are generally viewed to be important in post conflict societies. ${ }^{1}$ Their roles are however contested. ${ }^{2}$ Some have

1 Jeremy Sarkin and Tetevi Davi, "Examining the Criticisms Levelled Against Transitional Justice: Towards An Understanding of the State of the Field", Human Rights and International Legal Discourse, 11(1). (2017): 7-22.

2 David Mendlloff, "Truth-Seeking, Truth-Telling, and PostConflict Peacebuilding: Curb the Enthusiasm?" International Studies Review, 6 (2004): 355- 80; but see a more positive study Olsen, Tricia D., Leigh A. Payne, and Andrew G, Reiter, "Transitional Justice in Balance, Comparing Processes, Weighing Efficacy." (Washington, DC: United States Institute of Peace Press) 2010. challenged the extent to which these institutions have had positive effects, or have adequately addressed the human rights situation in that country on their own. ${ }^{3}$ The fact is that there have been more than 50 truth commissions that fall within the often-narrow definition of a TC (and many more if a wider definition is used). However, there have been many more of these institutions that some commentators do not include within the classification of a TC. The fact that such processes are so regularly established in so many places around the world indicates that they are widely recognised as playing at least somewhat important functions. Such institutions, and a range of other similar mechanisms, have multiple and varied objectives. Borer, for example, has argued that TCs have 26 different objectives. ${ }^{4}$ Obviously, the main area that TCs are involved in is truth gathering. Part of this exercise is about memory and can be more helpful than other tools in "devising a new national narrative." ${ }^{5}$ Another goal is accountability. Accountability is somewhat controversially linked to TCs as many have the perception that TCs actually reduce accountability as they often replace trials and retributive justice. However, it has been argued that TCs do not impact the human rights situation in a country without the accompanying trials and amnesties. ${ }^{6}$

Today, the right to the truth is recognised as an international right. In this context, the issue remains about how to ensure that victims enjoy that right in practice. While the right to the truth is available in a range of treaties and other international legal principles, the benefit to victims is not always realised. One institutional home for truth recovery, especially for the needs of victims, are truth commissions. Truth commissions are useful vehicles in this regard depending on how they are established and what resources they have at their disposal to embark on the truth collecting enterprise.

3 Johannes Langer, "Are Truth Commissions Just Hot-Air Balloons? A Reality Check on the Impact of Truth Commission Recommendations." Desafios 29.1 (2017): 177-210.

4 Anne Borer Tristan, 'Truth Telling as a Peace-Building Activity: A Theoretical Overview, in Telling the Truths: Truth Telling and Peace Building in Post-Conflict Societies, ed. Anne Borer Tristan (Notre Dame, IN: University of Notre Dame Press, 2006), 26.

5 Martha Minow, "Making History or Making Peace: When Prosecutions Should Give Way to Truth Commissions and Peace Negotiations", Journal of Human Rights, 7(2). (2008): 180.

6 Tricia D.Olsen; Leigh A. Payne; Andrew G. Reiter, and Eric Wiebelhaus-Brahm, "When Truth Commissions Improve Human Rights", The International Journal of Transitional Justice, 4 (2010): 457 476. 
The way in which amnesties are used, and can be used by truth and reconciliation commissions to gain truth remains an understudied area. Generally, when the topic is discussed it focuses on when amnesties are legally permitted in international law. ${ }^{7}$ When specific TCs are discussed, it is usually in relation to the South African process, which allowed its TC to grant amnesty that is discussed. While it is true that South Africa's conditional amnesty has been acknowledged as the most legally stringent and politically legitimate of amnesties established in post-conflict societies, ${ }^{8}$ it is still very controversial. ${ }^{9}$ In spite of it being democratically enacted through Parliament, ${ }^{10}$ at least one reason for the controversy surrounding the process is because it gave amnesty for all offences, and did not exclude serious international crimes. ${ }^{11}$

A number of TCs since the South African Truth and Reconciliation Commission have been given the power to recommend to government that amnesty is granted to individual perpetrators who have committed offences. None of these later institutions were actually given the power to grant amnesty. Countries where TCs were involved in recommending amnesties include the processes in Grenada, Indonesia, the Democratic Republic of the Congo (DRC), in Timor-Leste/Indonesia in the joint Commission on Truth and Friendship (CTF), and Liberia to name a few. A number of other processes were to be established with such powers, however they were either never set up, were struck down by the courts or never used their powers. These are discussed briefly in the article.

This article examines the amnesty powers granted to a variety of TCs. It considers whether the process by which TCs are able to recommend amnesty to specific perpetrators who cooperate with TCs and provide truth, has ensured that such individuals come forward and cooperate. This is decisive, as TCs "experience di-

7 Francesca Lessa, Amnesty in the Age of Human Rights Accountability: Comparative and International Perspectives, ed. Payne, Leigh A.(Cambridge University Press 2014; Cambridge, U.K).

8 Richard A. Wilson, The Politics of Truth and Reconciliation in South Africa - Legitimising the Post-Apartheid State, (Cambridge University Press 2011; Cambridge) 23.

9 Mark Freeman, Necessary Evils: Amnesties and the Search for Justice (Cambridge University Press 2009; Cambridge, U.K.).

10 Jeremy Sarkin, "The Development of a Human Rights Culture in South Africa" Human Rights Quarterly 20(3), (1998): 628-655.

11 Louise Mallinder, Amnesty, Human Rights and Political Transitions: Bridging the Peace and Justice Divide.( Bloomsbury 2008; U.K.). fficulties in obtaining detailed perpetrator testimony." 12 Crucially, unlike the South African TC that - as discussed below - had the power to directly grant amnesty, later TCs were only able to recommend to their governments that amnesty be granted to specific persons who had met the criteria laid out in the specific TC's legal mandate. ${ }^{13}$

All these institutions had different provisions as to when, and for what reasons they could make such a recommendation that amnesty be given. The only process that was different, where the commission could not recommend amnesty for perpetrators, was that which occurred in Timor-Leste from 2001. This process allowed the truth commission to assist perpetrators to obtain immunity, ${ }^{14}$ through a community reconciliation programme. ${ }^{15}$ It must be noted that immunity was to be given, not amnesty. The ability to grant immunity to perpetrators in Timor-Leste however was not in the remit of the commission. It had to be done by the commission in association with the prosecuting authority and with the concurrence of the courts. However, as discussed below, the only recommending model where perpetrators entered the process in any numbers was the one in Timor-Leste. There, perpetrators knew their names were known, seemed to trust the process more, and had more certainty that once they entered the process, a positive outcome would result.

This article touches on some of the problems that may occur during such processes; problems that need careful evaluation to ensure that perpetrators enter a conditional amnesty process and tell the truth once they have entered the process. ${ }^{16}$ The lessons learnt from the various processes where amnesty was directly granted (South Africa) and those where the TC only had powers to recommend amnesty are compared to determine what best practises be recommended for future conditional amnesty processes in TC activities.

12 Natalie Pierce, "Picking up the Pieces: Truth and Justice in Sierra Leone.” NZJPIL 6 (2008): 117, 120.

13 Amnesty International, Commissioning Justice: Truth Commissions and Criminal Justice, April 2010, at 5.

14 Chega Part 9, paras. 3-4.

15 Patrick Burgess, "Justice and Reconciliation in East Timor: The Relationship between the Commission for Reception, Truth and Reconciliation and the Courts," Criminal Law Forum 15 (2004): 135-158.

16 See for example Rudi Teitel, "The Law and Politics of Contemporary Transitional Justice"

Cornell International Law Journal 38(3) (2005): 836-62. 


\section{Providing Amnesty to Perpetrators}

States that want to deal with past conflict employ a series of mechanisms to achieve peace and lasting stability. ${ }^{17}$ As a result, in post-conflict societies the use of amnesties is a common, yet contested tool. ${ }^{18}$ During the period between 1945 and 2011, 537 amnesties occurred in 127 countries. Of these, 398 amnesties materialised after $1979 .{ }^{19}$ The constitutions of 186 states mention either amnesty or pardon. Today, states are conducting amnesty proceedings as a recurring practice. ${ }^{20}$

Amnesty popularly perceived as a method to prevent perpetrators from assuming their responsibilities. It is often understood as a way of avoiding fairness and promoting impunity. ${ }^{21}$ At times, however, this mechanism should be understood as a tool for the reconciling society. ${ }^{22}$ Nonetheless is important to note that sometimes these processes do not use the term amnesty, but use a range of other similar terms. Thus, immunity, pardon and other such terms can be used, at times, interchangeably with amnesty. However, immunity, as a term, is legally different to amnesty. Thus, the UN Rule-of-Law Tools for Truth Commissions argues that: "the granting of amnesty should not be confused with granting use immunity which is acceptable under international law." 23 Thus, the key question is what does "Use immunity" or "immunity" means and how is it distinguished from amnesty? Immunity, legally speaking if it is applied in this sense, does not terminate criminal accountability or liability. It only ensures that certain evidence is precluded from being used in a case against a person. ${ }^{24}$ Thus,

17 Nesiah Vasuki "Transitional Justice Practice: Looking Back, Moving Forward" Research Report of Impunity Watch, (2016): 11.

18 Helena Cobban, Amnesty After Atrocity? (Paradigm Publishers 2007, New York, USA).

19 Louise Mallinder, “Amnesties' Challenge to the Accountability Norm? Interpreting Regional and International Trends in Amnesty Enactment", in Leigh A. Payne and Francesca Lessa, Amnesty in the Age of Human Rights Accountability: Comparative and International Perspectives (Cambridge University Press 2012, Cambridge, U.K.) 79.

20 Francesca Lessa and others, "Persistent or Eroding Impunity? The Divergent Effects of Legal Challenges to Amnesty Laws For Past Human Rights Violations" Israel Law Review 47, (2014):105.

21 Aryeh Neier, War Crimes: Brutality, Genocide and the Struggle for Justice (Times Books 1998).

22 Patricia Naftali, "Crafting a 'Right To Truth' in International Law: Converging Mobilizations, Diverging Agendas?”, Champ Pénal, 13 (2016).

23 United Nations OHCHR Rule-of-Law Tools for Post-Conflict States: Truth Commissions", 10-12.

24 Patricia Lundy. "Commissioning the Past in Northern Ireland" Review of International Affairs, 60 (2010). it is much narrower, and has less legal effect if defined in its common way, for the person to whom it is being applied.

There are different forms of amnesty such as conditional amnesty, limited amnesty and blanket amnesty. Self-amnesty, as some have argued, deserves to be in a separate group. ${ }^{25}$ Yet, it is also true that the three sorts of amnesty referred to above, could fall into the self-amnesty group.

A blanket amnesty is defined as covering all violations that occurred during a limited period of time. ${ }^{26} \mathrm{~A}$ limited type of amnesty, on the contrary, covers certain types of crimes, certain perpetrators, or certain time periods when the crimes were committed. Finally, a conditional amnesty is only given when the applicants fulfil certain requirements and conditions.

Various countries have used conditional amnesties as a mechanism to deal with the past. It can assist in truth recovery if amnesty is exchanged for truth. Conditional amnesties can usually provide substantially more truth than is currently the case in processes that typically rely on victim testimony. Amnesty should not be granted without perpetrators at least providing information about the acts for which they need amnesty.

Conditional amnesties are seen to be the most acceptable because they are the most accountable of all amnesties. Perpetrators have to provide something in return for amnesty. They have to go through a process. They are identified. Perpetrators are publicly named, which therefore should reduce impunity. Conditional amnesties seem to be more legitimate and reliable than amnesties that do not have any accountability. ${ }^{27}$ Indeed, they require some sort of responsibility and, at the same time, obtain truth recovery for victims. ${ }^{28}$ By definition, conditional amnesties give information about the identity of the perpetrators as well as the specific abuses they committed. Hence, truth telling becomes one of the main aspects of conditional amnesties. Depending

25 Kate Allan, "Prosecution and Peace: A Role for Amnesty Before the ICC?" Denver Journal of Internationa Law and Policy, 39 (2010): 239, 242.

26 Jacob Childers, "Amnesty, Revenge, and the Threat of Conflict Relapse” International Criminal Law Review 14.6 (2014): 1095-1122.

27 David Weissbrodt, “Review Of Andreas O’Shea, Amnesty For Crime In International Law And Practice" American Journal of International Law 97 (2003): 227.

28 Allan, "Prosecution And Peace: A Role For Amnesty Before The ICC?”, 239. 
on how the amnesties are applied they may prove to be quite useful truth-clarifying processes. With more transparency and a more open society when dealing with its past, greater guarantees of democratic stability can be achieved. Still, one of the main controversies is whether giving amnesties to perpetrators is more likely to benefit them than ensuring they are prosecuted for the crimes they committed.

As far as the usage of conditional amnesty for truth-seeking purposes is concerned, after the transitional justice process in South Africa, several countries have given powers to truth commissions to deal with amnesties. However those truth Commissions were often only given the power to recommend to governments that certain perpetrators should be amnestied in exchange for a specific set of conditions. These powers were provided in an attempt to enhance perpetrator cooperation with such processes that had largely not occurred before, without specific incentives for them to do so. Thus, a range of TCs were given such powers because one of the goals of TCs, often stated, is: "who did what to whom, when, where, and occasionally why." ${ }^{29}$ However, critical questions, which often remain unanswered, are asked about perpetrators, and, specifically who they are and what they did. This is because, generally speaking, these institutions rely on victims and their testimonies to achieve these purposes, as perpetrators in the main do not cooperate with such mechanisms. Thus, while TCs also conduct research, or collate research that was previously conducted depending on the available resources, it is victim testimony that is usually the major source of information for TCs. They are however, only part (and sometimes only a small part) of the overall picture of the past. This is because victims often have a very limited knowledge about the misdeeds that occurred. Their knowledge about who gave orders, what the chain of command was, who provided the arms and ammunition, who else was involved in the conspiracy and others is often incomplete. Victims have limited knowledge, as they may not even have been present when the atrocity was committed. If they were present, they usually have very little knowledge about what planning went into it and what transpired. Despite victims knowing so little about what occurred to them or how the abuses in general were perpetrated, truth commissions, in general,

29 Cyanne E. Loyle and Christian Davenport "Transitional Injustice: Subverting Justice in Transition and Postconflict Societies", Journal of Human Rights, 15(1), (2015): 126-149. rely largely on their testimonies. ${ }^{30}$

At least an element of knowledge about the past lies with the perpetrators. However, with some limited exceptions, this group almost universally does not cooperate with TCs. These exceptions often occur for political reasons, where a high-profile person is already aware that what they have done is widely known, or because they wish to exploit what they have done for political reasons.

However, perpetrators fear the legal consequences of appearing before TCs without some sort of legal cover. They often seek legal assurances that the information they provide will not be used against them at a later stage in either criminal or civil cases. Thus, for perpetrators to participate they need to receive some incentive to encourage them to explain what they did and what the circumstances were. Indeed, the more incentives the perpetrators receive, the more information will be provided for truth recovery. Perpetrators would be more inclined to tell the truth when they are feeling less threatened by the prospect of being prosecuted. As Bisset notes:

If perpetrators suspect that there is a possibility that
amnesty will be refused and that their disclosures
might then be used to further investigations or
employed against them in subsequent trials they
will be less likely to participate, thereby limiting the
prospects for reconciliation. ${ }^{31}$

Realising the problems that perpetrators are reluctant to appear voluntarily before truth collection institutions, some processes have found ways to ensure that perpetrators do testify. They do this because they realise that if a primary objective is to create an authoritative record of the past and to provide some type of accountability for perpetrators ${ }^{32}$, then getting perpetrator cooperation is necessary even if it is only to some degree. Amnesties can thus be a tool to provide the truth about events and violations committed. Finding the truth about what happened helps to reconcile a society divided by its history. ${ }^{33}$ It establishes an ideal basis for

30 See issues concerning victim testimony, Moon, C Narrating Political Reconciliation: South Africa's Truth and Reconciliation Commission. (Lanham, U.K.; Lexington Books, 2008).

31 Alison Bisset, "The Privilege Against Self-Incrimination in Truth Commission-Administered Accountability Initiatives." Leiden Journal of International Law 30.1 (2017): 173.

32 Margaret Popkin, Truth without Justice, (University Park, PA: Pennsylvania State Press, 2000) 80.

33 Janine N. Clarke, "Transitional Justice, Truth and Reconciliation: An Under-Explored Relationship" International Criminal Law 
building a democratic state and for achieving a united society. ${ }^{34}$

For this reason, some TCs are given, and employ powers of subpoena, or search and seizure powers in order to get perpetrators to appear and testify or to find information. ${ }^{35}$ Some processes, such as that which occurred in Sierra Leone, have used these powers to coerce perpetrators to appear before the TC, by threatening to use such powers. Some processes allow potential witnesses to feel more protected by guaranteeing that information obtained cannot not be used in later legal proceedings against the perpetrator. Some institutions, like the TC in Liberia, have published the names of those believed to have committed crimes ${ }^{36}$ during the process in order to try and herd such people into the processes on the basis that, formally or informally, they will be rewarded for their cooperation by assurances of non-prosecution. ${ }^{37}$ Still other processes have collected information from perpetrators through vetting or lustration processes. These processes ensure that perpetrators, in order to keep their jobs or to obtain new ones, have to provide information about what they have done on pain of perjury and against investigations that check the veracity of their information.

In order to achieve a successful conditional amnesty the process must ensure that the perpetrators apply for that amnesty. Therefore, a conditional amnesty must have two essential components to be successful. Firstly, the process has to ensure the perpetrators decide to participate, while on the other hand, it has to ensure that the participation of these actors serves to clarify the whole truth. Regarding the first part, the applicants have to believe that the amnesty is necessary to them. If this were not the case, what would be the reason to

Review, 11 (2011):241.

34 Grace Fiddler, "Using A Conditional Amnesty And Truth And Reconciliation Commission As A Transitional Justice Mechanism In Syria" The George Washington Institute of International Law Review 47 (2015): 893, 917.

35 On the protections that ought to be available see Bisset, A "Principle 9: Guarantees for Persons Implicated" in The United Nations Principles to Combat Impunity a Commentary, eds. Haldemann and Unger, (2017) OUP.

36 On the shaming effect see Mendeloff, D. "Truth-Seeking, Truth-Telling, and Postconflict Peacebuilding: Curb the Enthusiasm?" International Studies Review, 6(3), (2004): 361.

37 Jeremy Sarkin and Tetvi Davi, "The Togolese Truth, Justice and Reconciliation Commission: Lessons for Transitional Justice Processes Elsewhere." Peace and Conflict Studies Journal 24(1), (2017): $1-27$. participate in such processes of conditional amnesty?

To make a conditional amnesty viable, it must begin by dealing some of the crimes committed by the perpetrators from the outset, or at least indicate its commitment to prosecute those who do not enter the amnesty process. Thus, a unit ought to be established and public pronouncements ought to be clear that prosecutions will occur for those who do not apply. By doing so, the perpetrators will see that availing themselves of an amnesty will benefit them and that not doing so will have ramifications. It demonstrates not only the state's ability to prosecute crimes and abuses, but also a clear political will to do so.

The second essential component of a viable amnesty is to ensure that the perpetrators involved in the process tell the truth about everything that happened. Thus, there must be mechanisms to ensure that the real truth is told and machineries of revocation of amnesty and perjury processes should be established. As far as revocation is concerned, if it were discovered that there was no proper cooperation or that the perpetrator did not reveal the truth, it should be possible to revoke the request for amnesty. In addition, there needs to be a clause dealing with perjury to avoid lies during the process. Such cases should even end with imprisonments and other penalties to dissuade those who might otherwise not use the process fairly.

The probability that a conditional amnesty will be viable increases if done within a simple framework that ensures the participation of perpetrators. Thus, following a pragmatic approach, it would help the perpetrators if they were to meet simplified requirements. The eligibility criteria for amnesty should be simple and easy to understand. The purpose of establishing easy criteria is to facilitate the participation of the perpetrators. However, it is also necessary to establish a unit of investigation that is dedicated to prosecuting the crimes and abuses committed by those who did not want to request amnesty. Therefore, criminal investigation of responsible actors should not be left out of the political process, and should go hand in hand with the amnesty process.

To make the amnesty viable, the perpetrators must see the need to apply for it. This should be done through some independent institution like a truth commission. It can be done though another process as long as the process is credible and trustworthy. While there 
are some who suggest that perpetrators might surrender without any amnesty condition and there are cases of perpetrators who have come forward, the reality is that very few perpetrators do so without the necessary incentives. The issue of perpetrator motivations is an understudied issue, but often their reasons for coming forward is personal. However, there may be institutional reasons for them to do so.

\section{The role of the South African tC in GRANTING AMNESTY}

This section examines the South African TC process as a comparative tool, as it is the only TC that has had the power to grant full amnesty. The power to grant amnesty was given to the $\mathrm{TC}^{38}$ as a result of a compromise between the conflicting parties during negotiations. An agreement was struck to allow an amnesty to occur that would allow the country to move to non-racial elections and democratic transformation. ${ }^{39}$ As assurances were sought that amnesty would occur, it was incorporated into the interim Constitution that was legislated in 1993 by the Apartheid regime. The interim Constitution entered into force when the democratic elections were held in April 1994. The next step in terms of dealing with the past was the establishment of the TC. Such a process was deemed the best way to deal with past human rights violations. After much parliamentary and public debate, the TC and amnesty process was established. ${ }^{40}$ It was perceived that the most legitimate, and best way, to obtain as much truth about the past as possible, was to link the truth-gathering exercise to the amnesty process. Thus, truth would be traded for amnesty and one of the goals of the TC was to facilitate "the granting of amnesty to persons who make full disclosure of all the relevant facts relating to acts associated with a political objective and comply with the requirement of this Act." The TC Act ${ }^{41}$ provided that:

38 South Africa, Promotion of National Unity and Reconciliation Act 1995.

39 Jeremy Sarkin, "Understanding the Journey to Reconciliation in Transitional Societies: Using the Metaphor of a Motor Vehicle Road Trip to Understand South Africa's Path (Process) to Political Reconciliation" International Journal of Renaissance Studies 10(2), (2015):109.

40 Promotion of National Unity and Reconciliation Act 34 of 1995.

41 Act 200 of 1993. amnesty shall be granted in respect of acts, omissions and offences associated with political objectives and committed in the course of conflicts of the past. To this end Parliament under the constitution shall adopt a law determining a firm cut-off date, which shall be a date after 8 October 1990, and before 6 December 1993, and providing mechanisms, criteria and procedures, including tribunals, if any, through which such amnesty shall be dealt with at any time after the law has been passed.

The TC legislation provided for three committees including an amnesty committee. As will be discussed later in the article, one of the reasons why people who seek amnesty enter such a process is because there is some degree of certainty that amnesty will be granted. Perpetrators are not usually willing to navigate a process where there is a great deal of doubt about whether amnesty will be granted. In this regard, the Amnesty Committee was somewhat insulated from the rest of the TC. People who, as a rule, inspired confidence were chosen to be on that committee as they were initially judges while others were seen to from the same political milieu as those from the security forces. Thus, those who may have had political issues with the TC Commissioners probably found solace in the fact that it was judges who were to make amnesty decisions.

The number of amnesty applicants in the South African process was far higher than that of any other amnesty processes where a TC was involved. This is not to argue that all or even most perpetrators applied. While 7,116 individuals applied for amnesty, of which 1,167 were granted, how many should have applied is unknown, but if there were to be an examination of the extent of violations committed during the Apartheid era, it is expected that there ought to have been more applicants. ${ }^{42}$ Crucially, the number of 7,116 applicants is not an accurate number as about 4,500 of them were not seen to be real applicants, but people in prison at the time who tried to use the process to get released, but had not actually committed politically related offences. ${ }^{43}$ Irrespective of this, the issue of whether a reasonable proportion of those who committed violations applied for amnesty is linked to the question about whether potential applicants believed they needed amnesty. The

42 Rajeev Bhargava, Restoring Decency to Barbaric Societies in "Truth versus justice: the morality of truth commissions” Eds. Robert I. Rotberg \& Dennis Thompson (Princeton University Press 2000, USA): 45, 65 fn 35.

43 Volume Six Section 1 Chapter 2 paragraph 74. 
number of applicants was affected by the fact that shortly before the cut off point for amnesty applications, the biggest trial for politically related crimes, known as the Malan trial, ${ }^{44}$ ended in the acquittal of all of the 23 accused. The defendants in that trial included a former minister of defence, other senior politicians and security force individuals, as well as a range of hit squad operatives. The message that the acquittals sent was that even if the state had the political will to prosecute, it did not have the capacity or the resources to effect successful prosecutions.

The lack of political will by the state to prosecute was seen in the fact that the prosecuting authority at that time had already shown reluctance to investigate and bring such cases to court because of their fears about what prosecuting some perpetrators might mean for the ruling party. For the amnesty process to be successful both the carrot and stick had to work: in other words there needs to be an inducement to get amnesty but there has to be a stick to indicate that amnesty is needed and that those who do not get amnesty will be successfully prosecuted. In other words, the carrot of amnesty is dependent on the stick of prosecutions. The two are inter-related and cannot operate without each other. Therefore, in the South African context the amnesty process was reliant on its counterpart: the criminal justice system. For the amnesty to work, the criminal justice system had to apply pressure on those who potentially needed amnesty. However, through words and deeds the impression given by the prosecutors was that the justice system would not deliver on such cases. Even the bringing to court of the Malan trial was an aberration. That trial was only prosecuted as a result of an independent task team, and the role of independent lawyers tasked to investigate and prosecute such cases. In any case, many obstacles were placed in their way that ensured no other cases were brought despite the lawyers and investigators wishing to do so. The prosecuting authority itself did not investigate many cases and this reluctance was seen as a sign by perpetrators that amnesty might not be needed by many of them. As a result, at least some prospective amnesty candidates did not enter the process. However, some applicants, at least from the security forces, entered into the process because they had some degree of belief in

44 Howard Varney and Jeremy Sarkin, "Failing to pierce the hit squad veil: A critique of the Malan Trial", 10 South African Journal of Criminal Justice, 141, (1997). the system. They were gratified that the system was not theoretically dependent on decisions of partisan TC commissioners. Those that did enter into the process, from the Apartheid regime side, had greater trust in the amnesty system, as it was to be administered mainly by judges who were independently appointed as judges. In fact, there was a great deal of trust in the judiciary by the white community, who believed that judges were of high standing and could be trusted to apply the law impartially. At that time almost all judges were white men who came from the same milieu as the applicants from the security forces. Judges were for the most part from the same social group as the apartheid instigators. In addition, those who applied for amnesty probably also believed that these judges would apply strict legal criteria that would permit no political decision-making. Some, however, in spite of this, believed that they did not need amnesty and were willing to take their chances that they would not need amnesty.

On the question of how much truth was achieved through the amnesty process it seems as though more truth, that would not otherwise have done so, emerged. However, it seems as though some applicants colluded with each other in order to conceal what they knew. The lead investigator in one of the cases has noted that the applicants:

presented a well-oiled account of events that carefully interlocked and reinforced each other's versions in many aspects. Some sections of their written applications even used identical script and turns of phrase, leaving the impression that they could have been contrived and selective on detail. ${ }^{45}$

These kinds of problems could have been avoided to some degree by an adequate investigation process. Deficiencies in investigations because of a lack of staff, resources as well as other difficulties did not allow for sufficient investigations to determine the veracity of what applicants testified to. The limited role of victims during the amnesty process also affected the ability of applicants to be less than truthful as the credibility of their versions of what occurred was not always tested or tested adequately. Victims were not usually informed about what candidates had stated in their applications. Many victims failed to get to amnesty hearings either because they were not informed about them, or not in-

45 Piers Pigou, "Degrees Of Truth: Amnesty And Limitations In The Truth Recovery Project" in The Provocations of Amnesty: Memory, Justice and Impunity, Eds. Villa-Vicencio, Charles; and Doxtader, Erik (Cape Town, 2003). 
formed with time enough to allow them to put forward alternative versions of what was being said. ${ }^{46}$ An adequate investigation process and methods that ensured a better role for victims (situations that should have been in place anyway) would have been a way to provide a further check on the testimony of applicants. Obviously, this will not always be the case but is dependent on what violation was committed and whether there are victims with direct knowledge of what occurred.

Overall, it can be concluded that there were positive and negative aspects of the SA TC's amnesty process. Certainly, giving the TC the power to directly grant amnesty, with that power being exercised by professional judges appointed through the usual judicial appointment processes, seems to have had a positive effect on the process. The negative aspects of the process were the parallel lack of commitment by the state to investigate cases at the time. This indicates a true commitment to prosecute those who did not apply or who were refused amnesty. The amnesty law and how it worked was also problematic. The process was too complicated, too cumbersome and too slow.

A lesson from the South African process is that the number of people applying for amnesty is dependent on a number of factors, which include how the amnesty process is established, what the law is, what the criteria are, and whether the process engenders trust. These components are all important in influencing the decision by the perpetrator as to whether or not they will enter the process. Crucially, it is not only the law and the institution granting amnesty that are the determinants about whether potential applicants decide to apply. Perpetrators also evaluate whether they need amnesty or not. If they believe that there will not be prosecutions, or that these prosecutions will be unsuccessful, then they are less likely to apply. Thus, there needs to be a rigorous, independent investigation and prosecuting process to indicate capacity and willingness to prosecute those who do not enter the amnesty process.

Another lesson from the South African process for future conditional amnesty processes, whether administered by TCs or not, which will limit the possibility of applicants not telling the full truth, is that there needs

46 Jeremy Sarkin, "An Evaluation of the South African Amnesty Process" in Truth and Reconciliation: Did the TC Deliver. Eds. Chapman, Audrey and Van der Merwe, Hugo (University of Pennsylvania Press, Philadelphia 2008): 93-115. to be a provision that amnesty can be withdrawn if it is later found that full disclosure had not occurred. There must however be a provision about what process should occur after the TC is no longer in existence. Thus, it is essential that there is an institution that can make such a determination later. This could be a court or the prosecuting authority that is given such jurisdiction. Thus, an on-going mechanism to take up such matters would act somewhat as a bulwark again perpetrators being loose with the truth.

A useful provision in the South African law allowed perpetrators to be summoned to appear at a hearing under subpoena where they had to reveal the truth under pain of prosecution. These powers, as well as search and seizure provisions, which the SA TRC hardly used, are useful mechanisms that drafters of other TC laws could consider.

The final issue to note as far as the impact of the South African process is concerned is that the South African model:

helped turn truth commissions into a widely recognised solution for dealing with the past. Truth commissions therefore emerged as a standard tool to master political transition processes successfully. ${ }^{47}$

However its amnesty process has not been replicated anywhere else. What has occurred is that the South African legislation has been copied elsewhere to some degree, but not exactly. For example, the Kenyan TJRC's provisions replicated the SA TC provisions, in places, word for word. However, the Kenyan TJRC, as is discussed later, did not use these provisions as it saw its power to recommend amnesty as being too limited to draw perpetrators in. Other countries have used TCs in amnesty processes, although none have given the power to a TC to grant amnesty, but simply to recommend. The SA TC amnesty model has not been used elsewhere because of the problems in the process. South Africa's amnesty process has been tainted by the fact that almost no prosecutions have occurred in the wake of the process. ${ }^{48}$ This is because the system of giving amnesty was sold to victims and to the country as a whole, many

47 A.K. Krueger, The Global Diffusion of Truth Commissions: An Integrative Approach to Diffusion as a Process of Collective Learning, 45 Theory and Society 143-168 (2016) 155.

48 Jeremy Sarkin, "Dealing With Enforced Disappearances in South Africa (With a Focus on the Nokuthula Simelane case) and Around the World: The Need to Ensure Progress on the Rights to Truth, Justice and Reparations" Speculum Juris 1, (2015). 
of whom were not happy that amnesty were to be given, on the basis that prosecutions would occur after the process for those who did not apply or who were refused amnesty. The fact that prosecutions did not occur went against the pact that those who did not own up and give information would face the law. The fact that this did not occur has substantially undermined the South African amnesty process. It was also undermined by perceptions about how much new truth was obtained. Offenders were able to avoid giving the real truth, or avoid giving the full truth, because there was little in the way of a verification process.

\section{Truth Commissions With the power to RECOMMEND AMNESTY}

The next section examines the TCs that have had the power to only recommend amnesty to the state, or to a specific arm of the state, such as attorney generals or others. The distinction between the ability of an institution to grant an amnesty versus the capability of simply making a recommendation is crucial. Generally, the authority to grant an amnesty or pardon is a power that states are unwilling to devolve to an institution that cannot be controlled politically. Thus, there is a tension between creating a TC that is independent, and then trusting that institution with the power to grant amnesty. For this reason, there has been reluctance by governments to give to TCs, besides the South African TC, the power to directly give amnesty to perpetrators. Part of the problem is that the model of giving this power to TCs is somewhat tainted by the South African process. Since the South African TC amnesty process there have been a number of TCs that have only been given the authority to recommend amnesty. The next parts of this article evaluate how those models have worked in practice to determine what lessons can be ascertained.

\subsection{Grenada}

The first TC model considered with the power to recommend amnesty occurred in Grenada in 2001. The Grenadian TC was given the authority " $[\mathrm{t}]$ o recommend indemnity to various persons who give what is conside- red to be truthful evidence at the enquiry." ${ }^{49}$ The $\mathrm{TC}^{50}$ deemed this to mean that witnesses could be "favourably considered for the grant of amnesty or exemption from prosecution." ${ }^{51}$ It was however insufficient to tempt perpetrators into testifying about what crimes they had committed. The TC recognized that the inability to directly provide some type of immunity or amnesty was an obstacle to its effective functioning and in being able to elicit more truth. The TC in its final report thus noted:

It is the belief and understanding of the Commission that there are persons who might have made themselves available to appear before it and testify if they could have been given assurance of protection against prosecution; and that there were persons who appeared before the Commission and did give evidence, but were inhibited from speaking 'the truth, the whole truth and nothing but the truth' for fear of playing into the hands of the prosecuting authorities. ${ }^{52}$

Thus, it seems that the fact that uncertainty existed as to whether a person would be granted some type of legal protection undermined their willingness to enter the process. The fact that a perpetrator first had to give information and only later be considered for some type of indemnity by the state seemed to have been too indeterminate, and risky for potential applicants.

\subsection{Timor-Leste}

The second example considered here of a TC recommending amnesty, although again the process was to recommend immunity, was the Commission for Reception, Truth and Reconciliation (CAVR) TC process established in 2001 in Timor-Leste. ${ }^{53}$ It must be noted

49 Grenada "Terms of Reference of the Truth and Reconciliation Commission", in Truth and Reconciliation Commission, Report on certain political events which occurred in Grenada 1976-1991, 28 March 2006.

50 See further Geoff Dancy, Hunjoon Kim and Eric WiebelhausBrahm, "The Turn to Truth: Trends in Truth Commission Experimentation" Journal of Human Rights, 9(1) (2010): 45-64.

51 Grenada "Terms of Reference of the Truth and Reconciliation Commission", in Truth and Reconciliation Commission, Report on certain political events which occurred in Grenada 1976-1991, 28 March 2006. Volume 1 Part 7.

52 Grenada "Terms of Reference of the Truth and Reconciliation Commission", in Truth and Reconciliation Commission, Report on certain political events which occurred in Grenada 1976-1991, 28 March 2006. Volume 1 Part 7.

53 Jeremy Sarkin, "Achieving Reconciliation in Divided Societies: Comparing the Approaches in Timor-Leste, South Africa and Rwanda" Yale Journal of International Affairs 3(2); (2008): 11- 28. 
that there have been two TCs focused on Timor-Leste this one established by the UN Transitional Administration in East Timor (UNTAET) ${ }^{54}$ and the Commission on Truth and Friendship (CTF) which was a joint TC established by Timor-Leste and Indonesia after the CAVR. The CTF amnesty process is considered below.

The CAVR process in Timor-Leste was mandated to: "inquire into human rights violations committed on all sides, between April 1974 and October 1999, and facilitate community reconciliation with justice for those who committed less serious offenses." It provides, however, another example of perpetrators not coming forward without being given a priori immunity or amnesty for their stated actions. A critical issue is that many of the main perpetrators were not in the country but had fled to and were protected by Indonesia.

By January 2004 the CAVR had taken 7,000 testimonies, none of which, however, came from perpetrators. ${ }^{55}$ Part of the reason for this was that the CAVR was not permitted to recommend or grant amnesty. However it had a Community Reconciliation Process $(\mathrm{CRP})^{56}$ that sought to obtain the truth about what had occurred and achieve reconciliation, as well as to ensure the reintegration of perpetrators back into their communities. ${ }^{57}$ It was meant to be "a cheaper, faster, less complicated process." ${ }^{58}$ The process was established to permit a person who went through this process successfully to be granted immunity from all civil or criminal liability. ${ }^{59}$ The regulations initially provided that the Commission could not bring people that had committed "serious" offences into the CRP process. Crimes were defined as

54 Patrick Burgess, "Justice and Reconciliation in East Timor: The Relationship Between the Commission for Reception, Truth and Reconciliation and the Courts" Criminal Law Forum 15; (2004): 135-138.

55 Natalie Pierce, "Picking Up The Pieces: Truth and Justice in Sierra Leone", New Zealand Journal of Public and International Law 6(2), (2008) 117-156.

56 Padraig McAuliffe, "East Timor's Community Reconciliation Process as a model for legal pluralism in criminal justice" Law, Social Justice and Global Development, 2, 12 (2008).

57 Commission for Reception, Truth and Reconciliation in East Timor "Chega! The Final Report of the Commission for Reception, Truth and Reconciliation in East Timor" (2005) in http://www.etan. org/news/2006/cavr.htm

58 Patrick Burgess, "East Timor's Community Reconciliation Process", in Transitional Justice in the Twenty-First Century: Beyond Truth versus Justice, Eds. Naomi Roht-Arriaza and Javier Mariezcurrena, (2006): 176-205, 184.

59 Chega!, Report of the Commission for Reception, Truth and Reconciliation for East Timor, (2006). serious depending on their nature, how many had been committed and the specific role of the perpetrator. ${ }^{60}$ The regulations were later amended, because of problems relating to the functioning of the Office of the General Prosecutor (OGP) and the debate around who should enter the CRP. The wording was changed so that "in principle" serious crimes could not fall within the mandate of the CRP process. Thus, exceptions were permitted and some people who committed serious crimes were allowed to apply.

To gain immunity, the person had to voluntarily submit a written declaration setting out in full detail what they had done, and how they were linked to the political conflict. ${ }^{61}$ The deponent then had to provide an oral version of the deeds for which reconciliation was sought. The person had to admit responsibility and conduct an "Act of Reconciliation" to get such immunity. ${ }^{62}$ However, before this could occur the OGP had to deliberate on the case and approve it for CRP, rather than prosecution. After the hearing, if there was concord on the application by all the various role-players, a Reconciliation Agreement was drafted. After it was agreed to by a court of law it become a Court Order and was therefore binding.

Interestingly, the Commission sent all 1,541 CRP statements that it received to the OGP, of which $85 \mathrm{ca}-$ ses were refused by the GP. ${ }^{63}$ Each of the 85 cases that were refused by the GP involved low-level perpetrators who provided detailed statements to the CAVR without any legal advice and without legal protection. ${ }^{64}$ There was no mechanism whereby if they were not integrated via the CRP, that the information they provided would not be used against them in the eventuality of a prosecution. ${ }^{65}$ These individuals seemingly believed that

60 Natalie Pierce, "Picking Up The Pieces: Truth and Justice in Sierra Leone", New Zealand Journal of Public and International Law 6(2), (2008) 117-156, 147.

61 Padraig McAuliffe, East Timor's Community Reconciliation Process as a model for legal pluralism in criminal justice, 9.

62 Spencer Zifcak, "Restorative Justice in East Timor: An Evaluation of the Community Reconciliation Process of the CAVR" Asia Foundation, 2004.

63 Commission for Reception, Truth and Reconciliation in East Timor "Chega! The Final Report of the Commission for Reception, Truth and Reconciliation in East Timor" (2005)

64 Patrick Burgess, "East Timor's Community Reconciliation Process", in Transitional Justice in the Twenty-First Century: Beyond Truth versus Justice, Eds. Naomi Roht-Arriaza and Javier Mariezcurrena, (2006): 176-205, 195-196.

65 Alison Bisset, "The Privilege Against Self-Incrimination in Truth Commission-Administered Accountability Initiatives." Leiden 
they did not need such protection, as they would not be prosecuted because they had entered the reintegration process. It was only the fact that there was a large caseload that saw those cases not being taken up by the prosecutors. ${ }^{66}$ However, there is an anomalous situation, as discussed below, that these people were given no protection against self-incrimination, which was the case for those persons who were subpoenaed to appear before the CAVR. ${ }^{67}$

Hearings were held for the applicants in 1,371 cases. Again, no protection was provided to insulate them from what they testified to at the hearings. It seems that all those who testified believed that they would be getting amnesty. However, during the proceedings 32 cases were interrupted because, according to the Chega Report, credible information was received that the applicant may have committed a "serious criminal offence," or because the community would not go along with the request for immunity. ${ }^{68}$ Overall, nearly 90 percent of all cases ended up with immunity. The remaining 10 percent (170 cases) did not end with a positive granting of immunity because the applicant did not appear at their hearing, problems were raised at the hearing, or because the GP did not agree to the case continuing through this process. ${ }^{69}$

As far as the outcome of the process as a whole is concerned both McAuliffe and Burgess argue that the CRP was very successful. ${ }^{70}$ Pigou found that "there is a widespread feeling that the CRPs have definitely contributed to building social cohesion and relieving tensions in many places. ${ }^{, 71}$ However, Burgess makes it clear that it is difficult to draw lessons from the CRP because it was designed and operated in the local context. ${ }^{72}$ Regardless, a 90 percent success rate for those who entered the process is very high. It is, however necessary to understand the reasons for this. It must be recognised that the bulk

Journal of International Law 30(1) (2017): 155-176, 160.

66 Chega!, Part 9, para. 169.

67 Alison Bisset, "The Privilege Against Self-Incrimination in Truth Commission-Administered Accountability Initiatives.” Leiden Journal of International Law 30.1 (2017): 160.

68 Chega Part 9, para.102.

69 Chega Part 9, para.102.

70 McAuliffe, East Timor's Community Reconciliation Process as a model for legal pluralism in criminal justice and Burgess, East Timor's Community Reconciliation Process, 176.

71 Piers Pigou, "The Community Reconciliation Process of the Commission for Reception, Truth and Reconciliation”, UN Development Programme, (2004): 84.

72 Burgess, 176. of the architects of the violence, and many of the high level, and even some at the lower level, perpetrators were not in the country. They were in Indonesia and as a result, most of the people who applied were people who were involved in the violence, but not at leadership levels. Also Timor-Leste is small and most of the actors involved in the violence were known. The perpetrators continued to live amongst their victims. This makes it easier to understand the high rate of community reconciliation efforts as well as the willingness to reintegrate many of these people. They were part of the community, and there were no specific divisions or schisms between them and their communities. However, it must be noted that there were "in excess of 3,000 perpetrators" in Timor-Leste, who did not enter the process. This was largely because they did not know about the CRP, did not understand it, and by the time they found out about it the time for applications had passed. ${ }^{73} \mathrm{~A}$ lesson, therefore, is that education around such processes and their benefits enhances participation.

Still, the relatively high numbers of applications, 1,371 persons - compared to other processes where TCs had powers only to recommend amnesty - must be understood in the context of what else was happening in Timor-Leste at the time. As noted earlier, people apply for amnesty if they believe they need it. They do so because they believe that it is likely that they could be prosecuted otherwise. This was the case in Timor-Leste, as the Special Panels of the Dili District Court had already been established in 2000 by UNTAET to prosecute such offences. ${ }^{74}$

The fact that Timor-Leste was being administered by the UN and the Security Council had already adopted, in 1999, Resolution 1272 which ordered that "those responsible for such violence be brought to justice" 75 , was a clear sign to perpetrators that the political will to prosecute offenders existed. This view was cemented when the special Panels were created. This hybrid court process was already handing down verdicts in December 2001.

A critical issue in this process, similar to the one in Sierra-Leone, was the timing and sequencing of the

73 Burgess, 196

74 Suzanne Katzenstein, "Hybrid Tribunals: Searching for Justice in East Timor", Harvard Human Rights Journal, 16. (2003):245-278.

75 Taina Jaervinen, "Human Rights and Post-Conflict Transitional Justice in East Timor", UPI Working Papers 47, Finnish Institute of International Affairs, (2004): 51. 
process. In Timor-Leste, the timing was important as the CAVR began its work formally in July 2001 and ended its work on December 20, 2005. ${ }^{76}$ When the CAVR began its work, prosecutions before the courts were already in full swing, so at least some perpetrators knew that prosecutions were occurring and that they could be put on trial. This knowledge is cemented by the fact that by the end of 2003, 367 people had already been charged with crimes, 84 percent of them being indicted for crimes against humanity. By then, there were already 38 convictions (all East-Timorese), for crimes against humanity and other serious crimes. ${ }^{77}$ These prosecutions, and the types of charges levelled, gave perpetrators, who lived in Timor-Leste the sense that they needed amnesty. For those who knew about the CRP and understood what it was about they were more likely to apply for amnesty. However, there was uncertainty about the process and a cultural belief about the shame associated with admitting to involvement in such crimes. It took a concerted outreach campaign to get people into the process. ${ }^{78}$ However, the outreach campaign was not as useful as it could have been as, by the end of the process there were still many people who had not heard of it or did not understand it if they had been made aware of its existence. ${ }^{79}$

In many ways, this process was a conditional amnesty. People got immunity/amnesty in exchange for truth and reconciliation. It has been noted that this process provided much truth which otherwise would not have been known ${ }^{80}$ and that it also provided "symbolic closure." $" 81$

It must be noted that then Prime Minister Xanana

76 Patrick Burgess and Galuh Wandita, "Reaching Out to Victims and Communities: The CAVR's Experiences in Timor-Leste," in Transitional Justice, Culture, and Society: Beyond Outreach, Ed. RamirezBarat (Colombia University Press, 2014). 143.

77 Taina Jaervinen, "Human Rights and Post-Conflict Transitional Justice in East Timor", UPI Working Papers 47, Finnish Institute of International Affairs, (2004): 51.

78 Patrick Burgess and Galuh Wandita, "Reaching Out to Victims and Communities: The CAVR's Experiences in Timor-Leste," in Transitional Justice, Culture, and Society: Beyond Outreach, Ed. RamirezBarat (Colombia University Press, 2014):156.

79 Patrick Burgess and Galuh Wandita, "Reaching Out to Victims and Communities: The CAVR's Experiences in Timor-Leste," in Transitional Justice, Culture, and Society: Beyond Outreach, Ed. Ramirez-Barat (Colombia University Press, 2014). 143.

80 Piers Pigou, The Community Reconciliation Process of the Commission for Reception, Truth and Reconciliation.

81 Padraig McAuliffe, East Timor's Community Reconciliation Process as a model for legal pluralism in criminal justice, 10.
Gusmão proposed an amnesty law in 2001. After he became President of the country such a law was drafted and presented to the Parliament. ${ }^{82}$ However, it was not adopted.

As far as powers to get information from perpetrators were concerned, the CAVR had both search and seizure, ${ }^{83}$ and subpoena powers. As far as subpoena powers are concerned, the law entitled the CAVR to compel individuals to appear and had to answer, under oath, questions that were put to them. ${ }^{84}$ They were protected in the sense that there could be no compulsion to give evidence that was self-incriminating or would implicate a close relative. ${ }^{85}$

Thus, the CAVR process and its outcomes must be seen to be very context specific. However, much can be learnt from these processes, which can then be implemented into processes that may be established in the future. All circumstances and their potential effects need to be considered when a process is started. However, linking processes of amnesty to reconciliation seems to have been somewhat successful.

\subsection{Indonesia-Timor-Leste Commission on Truth and Friendship (CTF)}

The third example of a TC's involvement with amnesty is that of the Indonesia-Timor-Leste Commission on Truth and Friendship (CTF) established in 2005. The CTF was jointly established by Timor-Leste and Indonesia to deal with crimes committed in Timor-Leste around Timor-Leste's independence.

The CTF Commission was given the authority to 'recommend amnesty for those involved in human rights violations who cooperate fully in revealing the truth'. ${ }^{86}$ The terms of reference given to the CTF provided that amnesty would be given to those: involved in human rights violations if they fully cooperated in establishing the truth. The CTF in its report noted that amnesty would only have been recommended if considerable assistance was provided to the CTF in finding the truth and if the person appeared before the Commission and

82 Taina Jaervinen, "Human Rights and Post-Conflict Transitional Justice in East Timor", UPI Working Papers 47, Finnish Institute of International Affairs, (2004): 64.

83 Section 15

84 UNTAET Regulation No. 2001/10 s. 14.1(c).

85 Section 17.

86 UNTAET Regulation No. 2001/10 S. 14, ss c, i-iv. 
admitted their role and responsibility in the incidents. ${ }^{87}$ However, no person was given amnesty. ${ }^{88}$ The CTF Report, "Per Memoriam ad Spem", notes that the Commission did not recommend "amnesty or rehabilitation for any persons." ${ }^{89}$ This is because perpetrators largely ignored the process and did not participate. Even closed hearings, and the fact that hearings took place in Indonesia did not sufficiently tempt perpetrators to come forward. Relatively few people participated in process in general. The CTF report notes that the Commission was able to collect statements and interviews from 108 out of a total number of 280 individuals it had identified as potential witnesses, ${ }^{90}$ composed of victims, witnesses and perpetrators. However, only 62 people gave testimony to the CTF. The list of names published in the Report, shows that the 62 people who testified were collectively victims, witnesses and perpetrators. Very few of the 62 were perpetrators, even though some of the hearings were held in Indonesia, and many were closed to the public. In fact, closed hearings were held five times in Indonesia and three times in Timor-Leste. Even closed hearings, and the fact that hearings took place in Indonesia did not sufficiently tempt perpetrators to come forward.

The Commission notes in its Report that no amnesties were recommended. The CTF found that no perpetrators met the standard that the commission had set for recommending a person for amnesty: attending a public hearing, telling the complete truth and providing full cooperation. ${ }^{91}$ Thus, it seems as though cooperation with the commission by perpetrators did not occur. This is probably the case, as perpetrators might have believed that they had no reason to cooperate. They were probably of the view that there were unlikely to be prosecutions, particularly in Indonesia where the bulk of perpetrators originated. There is also the chance that they did not cooperate because no amnesty was assured. They undoubtedly saw that amnesty was not guaranteed, as the commission had no power to grant amnesty, but was simply empowered to make recommendations

87 Cited by Renée Jeffery in "Trading amnesty for impunity in Timor-Leste" Conflict, Security \& Development 16 (1) (2016):199.

88 Jefferey, Trading amnesty for impunity in Timor-Leste 199.

89 Commission on Truth and Friendship Per Memoriam Ad Spem ('Through Memory to Hope'), Xviii

90 Commission on Truth and Friendship Per Memoriam Ad Spem ('Through Memory to Hope'), 28.

91 Commission on Truth and Friendship Per Memoriam Ad Spem ('Through Memory to Hope'), 296. about the granting of amnesty. Perpetrators must have calculated that they had a lot to lose by coming forward, and very little, if anything, to gain from participating in the CTF process.

\subsection{Liberia}

The fourth TC amnesty-recommending model considered is that which occurred in Liberia from 2005. ${ }^{92}$ In Liberia ${ }^{93}$ the law establishing the Truth and Reconciliation Commission, ${ }^{94}$ provided that the TC could recommend:

amnesty under terms and conditions established by the TC upon application of individual persons making full disclosures of their wrongs and thereby expressing remorse for their acts and/or omissions, whether as an accomplice or a perpetrator, provided that amnesty or exoneration shall not apply to violations of international law ad crimes against humanity in conformity with international laws and standards.

It was widely believed in the country that this model was adapted from the South African process. However these provisions are very different from the South African version as it only allowed recommendations to be made concerning amnesty. ${ }^{95}$ The Liberian version also limited the crimes available for amnesty to those that are not considered serious international crimes. ${ }^{96}$ This was not the case in South Africa where any crime was available to be amnestied. The Liberian TC's Rules of Procedure stated that:

Every witness seeking immunity from prosecution
or tort actions on account of statements made or
evidence given before the Commission pursuant to
Article VII, Section 30 of the TC Act, shall make
a formal application for such immunity and give
reasons for such a request in order to enable the

92 On the development of the TJ model in Liberia see Hayner, Priscilla B., and Centre for Humanitarian Dialogue. "Negotiating peace in Liberia: preserving the possibility for justice". Geneva: HD Centre for Humanitarian Dialogue, 2007.

93 Ezekiel Pajibo, "Civil Society and Transitional Justice in Liberia: A Practitioner's Reflection from the Field.” International Journal of Transitional Justice 2(1) (2007): 287-296.

94 Liberia, An Act to Establish the Truth and Reconciliation Commission (TC) of Liberia, 10 June 2005.

95 Ozonnia Ojielo, "Critical lessons in post-conflict security in Africa: the case of Liberia's Truth and Reconciliation Commission" Institute for Justice and Reconciliation, 2010.

96 Rosalia De la Cruz Gitau, "God willing, I will be back': Gauging the Truth and Reconciliation Commission's capacity to deter economic crimes in Liberia", African Security Review, 17(4) (2008): 64-78. 
Commission to make a decision on whether or not to grant the immunity requested. ${ }^{97}$

To persuade people to come before the TC, the institution published the names of 198 persons it believed, from testimonies the institution had already received, were responsible for committing various violations. ${ }^{98} \mathrm{It}$ named another 139 people as "persons of interest". ${ }^{99}$ In its final report, it named 182 people that it was recommending for prosecution. The commission did recommend a general amnesty to be given to children who had committed offenses, and that amnesty be made available for non-serious crimes to promote national healing and reconciliation if people admitted what they had done and expressed repentance. ${ }^{100}$

As far as providing amnesty to specific people is concerned, the Liberia TC recommended that: "all individuals who admitted their wrongs and spoke truthfully before or to the TC as an expression of remorse will not be recommended for prosecution." It named 38 people it recommended to receive amnesty out of a total of 17,000 people who testified before the commission. ${ }^{101}$ Thus, it seems as though few perpetrators came forward considering that nearly 150,000 people were killed and tens of thousands of violations were committed. ${ }^{102}$ Those who came forward seem to have feared prosecution because at least some of their names were on the lists that were published by the TC during its existence. Those lists seem to have induced a few perpetrators to come forward. They may have believed that because they had been publically ousted, they should risk testifying to potentially be recommended for amnesty. Despite this, it does seem as though that the vast majority of perpetrators were not actually prepared to testify without amnesty.

97 Rule 47 adapted from Section 30 of the Liberian TC Act.

98 Amnesty International Public Statement. AI Index: AFR 34/010/2008. Liberia: Will those investigated by the Truth and Reconciliation Commission ever be prosecuted? (2008)

99 Paul James-Allen; Aaron Weah and Lizzie Goodfriend, "Beyond the Truth and Reconciliation Commission: Transitional Justice Options in Liberia" (New York: International Center for Transitional Justice, 2010).

100 Liberia TC Report Volume 2 page 8.

101 See Aaron Weah, "Hopes and Uncertainties: Liberia's Journey to End Impunity" International Journal of Transitional Justice 6(2), (2012):331-343.

102 Julie A. Keil, "Liberia's TC: The road to rule of law or a dead end?." African Journal of Political Science and International Relations 11(8), (2017): 201-209.

\subsection{The Kenyan Truth, Justice and Reconciliation Commission (TJRC)}

In Kenya, the Truth, Justice and Reconciliation Commission (TJRC) was established in 2008, in the wake of the 2007/2008 post-election violence, which racked the country along ethnic lines. ${ }^{103}$ The violence erupted in the country after Mwai Kibaki was named the victor of the presidential election, and his electoral opponent, Raila Odinga alleged electoral fraud. More than 1300 people were killed in the violence.

A parliamentary statute, the Truth Justice and Reconciliation Commission Act, created the TJRC. ${ }^{104}$ While it was established as a result of a peace agreement after the electoral violence, the National Accord, the TC was not established to deal solely with that period. In fact, it was mandated to investigate the gross human rights violations and other historical injustices in Kenya between 12 December 1963 and 28 February 2008. One of its major goals was to gain as much truth about the violations in the mandated period as possible. The TJRC was instructed to establish a precise, comprehensive and historical record of the human rights abuses committed during that period.

To enhance truth recovery the TJRC Act contained various provisions to persuade those with information to be more forthcoming. A useful provision to try and encourage people to participate and provide information was a provision that there could not be criminal or civil proceedings or a penalty or forfeiture for any information or evidence given by a person in the proceedings. ${ }^{105}$ The TJRC was also given powers to recommend amnesty to perpetrators who cooperated with it in its quest for the truth. ${ }^{106}$ Initially, the TJRC was given free reign to decide on the types of crimes for which amnesty could be recommended, before approaching the Attorney General. ${ }^{107}$ Later, the law was amended to narrow down the crimes for which amnesty could be recommended. The Act was very detailed concerning the amnesty process. Much of the Act follows the South African legislation with many parts being copied exac-

103 Evelyne Asaala, "Exploring transitional justice as a vehicle for social and political transformation in Kenya." African Human Rights Law Journal 10(2), (2010): 377-406.

104 No. 6 of 2008.

105 Section 24(3) of the TJRC Act.

106 Section 34 of the TJRC Act.

107 Kenya, The Truth, Justice and Reconciliation Act 6 of 2008, 28 November 2008. 
tly. However, the negative aspects of the South African process, which reduced its efficacy, had also been replicated. Thus, the South African process had not been sufficiently understood and similar provisions were incorporated which had similar negative effects. The onerous and complex legal criteria of the South African process, which had been duplicated, also could have reduced the numbers of applicants. Thus, the Kenyan TJRC amnesty process was very detailed and the criteria to be met by applicants were very comprehensive.

The law determined that applications for amnesty had to be in writing, had to comply with the Act and that there had to be full disclosure. ${ }^{108}$ The TJRC was entitled to hold hearings on amnesty applications. ${ }^{109}$ As with the South African process, the burdensome, complex and extensive criteria of the TJRC process probably had the effect of reducing the number of perpetrators who viewed the process in a positive light and who were willing to navigate its course. However, once again, the biggest problem with the TJRC amnesty process was that the institution only had the power to recommend amnesty, and not grant it. This was not something that perpetrators saw as credible. They were seemingly reluctant to rely on the power given to the TC to make recommendations. Ronald Slye, one of the international commissioners on the TJRC, has noted that because the commission could only recommend amnesty:

\footnotetext{
"The weakened provisions effectively nullified any impact of amnesty in the Kenyan process, while at the same time providing the mistaken perception that the Kenyan Commission had controversial amnesty powers..."110
}

Slye notes further, that the "powers of the Kenyan Commission were so severely limited that they were unavailable as a tool for the Commission to use to entice perpetrator testimony or foster reconciliation." Thus, it seems that few perpetrators were willing to avail themselves of the supposed benefits of amnesty. In this regard, the TJR noted in its final Report that it had decided not to exercise its powers to recommend amnesty. ${ }^{111}$ It states that it did this because it believed

108 Section 38.

109 Section 36.

110 Ronald C. Slye, "Putting the J into the TC: Kenya's Truth Commission: Forthcoming in Twenty Years On: Other Ways of Being and the South African Truth Reconciliation Commission", Seattle University School of Law Research Paper, 17(08), (2017):26.

111 Truth, Justice \& Reconciliation Commission, "The Final Report of the Truth, Justice \& Reconciliation Commission of Kenya" (2013), http://digitalcommons.law.seattleu.edu/tjrc/1 that few crimes would fit into the scope of what was envisaged, but more importantly it argued that: "the fact that it could only recommend and not grant amnesty, the Commission did not anticipate that much additional truth would come out of the amnesty process." Thus, the Commission noted that its powers to recommend amnesty alone was not something that was useful to it in the exercise of its mandate. In fact, the TJRC notes in its final Report that the limited amnesty powers given to it were not useful to it in gaining truth. ${ }^{112}$

\subsection{Republic of Korea}

Various attempts to deal with Korea's past have been attempted over the last seven or so decades. Some suggest that since 1996 there have been some eighteen TCs. ${ }^{113}$ This article will only deal with the most comprehensive and influential of those efforts: ${ }^{114}$ the $2005^{115}$ Truth and Reconciliation Commission of Korea (TCK). ${ }^{116}$ It was tasked to investigate the period 1910 to 1993. ${ }^{117}$ The focus is also on the amnesty process and extent to which it benefitted truth recovery.

The TCK Act gave the Commission the authority to recommend 'immunity' to those who cooperated with it. ${ }^{118}$ Article 30 provides that a person "who obtains or submits critical materials for clearing up the truth in the investigation, and may recommend he/she be granted amnesty." 119 Article 38 (Reconciliation for Victimizer Cooperating with the Investigation) provided that a perpetrator who actively cooperated and confessed their crimes could get the TCK to recommend immunity or the mitigation of punishment. The TCK could also recommend to the President that a pardon or exoneration be given.

112 TJRC Report Volume 1, paragraph 125.

113 Tae-Ung Baik. "Fairness in Transitional Justice Initiatives: The Case of South Korea." Buffalo Human Rights Law Review. 19 (2012):169, 170.

114 Andrew Wolman, "Looking Back While Moving Forward: The Evolution of Truth Commissions in Korea." Asian-Pacific Law \& Policy Journal 14(3), (2012): 27.

115 Ibid.

116 Framework Act on Clearing Up Past Incidents for Truth and Reconciliation by Law No. 7542, May 31, 2005.

117 Tara J. Melish, "Implementing Truth and Reconciliation: Comparative Lessons for the Republic of Korea." Buffalo Human Rights law Review. 19 (2012):1.

118 Art. 38.

119 Republic of Korea TC, Truth and Reconciliation Activities of the Past Three Years (2009):123. 
These powers were similar to that which the earlier Presidential Truth Commission on Suspicious Deaths, established in 2000, had sought to establish. It seems as though neither process saw the recommendatory function as useful. As a result of the 2005 Commission, only having the power to recommend immunity/ amnesty to other state actors, few perpetrators were willing to come forward and few were willing to work with the TCK. ${ }^{120}$ Dong-Choon has noted that: "few veterans have been willing to come forward." "21 The power to subpoena people was available, but the Commission had limited powers to compel compliance and little sanctioning power to use against those who did not comply. ${ }^{122}$ It has been found that "the TCK rarely issued an order compelling a person to appear before it and never penalised anyone for refusing to appear before it. ${ }^{123}$

Thus, it seems that, as with the other TC processes, giving a TC the power to recommend amnesty does not achieve positive results unless the process is delineated carefully and publicised widely, as occurred in Timor-Leste. It must also be noted that if a TC is against such provisions and does not possess the will to implement them then the process is doomed from the start. Far more ought to be done to educate those in such processes about the benefits of these processes. However, because amnesty provisions are often criticised, much needs to be done during the drafting phase of TC legislation to craft a law that contains useful provisions. But, there also needs to be sufficient consultation and education on these provisions to garner support for them, in order to eliminate negative perceptions when the TC begins its work.

\section{Other tC Amnesty Processes}

A number of other similar TCs have occurred around the world that had amnesty powers. These will not yet been analysed in much depth because they have not come to fruition, or have not yet terminated.

As with the other TCs that had powers of amnesty, the Democratic Republic of Congo (DRC) was only

120 Dong-Choon Kim, "Korea's Truth and Reconciliation Commission: An Overview and Assessment." Buffalo Human Rights Law Review 19 (2012): 97, 107.

121 Ibid.

122 Ibid.

123 Ibid. able to recommend amnesty. ${ }^{124}$ The TC was established as a constitutional mechanism in the 2003 Constitution of the Transition. ${ }^{125}$ The law established that it had to deal with matters between 1960 and 2006. It was mandated to 'establish truth and to promote peace, justice, reparation, forgiveness and reconciliation for sustaining national unity. ${ }^{126}$ However, the TC did not investigate any cases and made no recommendations about the granting of amnesty. ${ }^{127} \mathrm{~A}$ proposal for a subsequent TC, recommended that it "receive all demands for amnesty, examine their legitimacy, and grant or refuse it." ${ }^{128}$ In other words, the TC should be given the power to grant amnesty and not simply recommend it, as had been the case previously. This suggests that the TC saw the power to recommend amnesty only as of limited value and therefore was suggesting that for amnesty to have effect the TC needed to have the power to actually grant amnesty.

Another TC that was to have amnesty provisions was that created by a law in Indonesia in 2004 to deal with crimes that had occurred there. The law provided that the institution would be able to receive confessions and apologies, and then recommend to the President of the country which persons would be given amnesty. ${ }^{129}$ Because the Constitutional Court of Indonesia in 2006 ruled that the statute was incompatible with the 1945 Constitution, ${ }^{130}$ the TC was never established. Thus, little can be learnt from this example other than it being an example of a model where truth was to be traded for amnesty.

In Nepal, an early draft of a TC law in 2007 contained a provision that the institution would have had the power to recommend amnesty if the perpetrator applied for it and submitted an amnesty application

124 Loi No. /04/018 du Juillet 302004 portant sur l'organisation, attributions et fonctionnement de la Commission Vérité et Réconciliation, article $8 \mathrm{~g}$.

125 Constitution of the Transition, article 154 (2003).

126 Olivier Kambala and Tyrone Savage, Decayed, Decimated, Usurped and Inadequate: the Challenge of Finding Justice through Formal Mechanisms in the DR Congo, Ivo Aertsen et al., "Restoring Justice after Large-Scale Violent Conflicts", (Cullompton and Portland, Willan Publishing; Devon, U.K. 2008): 346.

127 Laura Davis and Priscilla Hayner "Difficult Peace, Limited Justice: Ten Years of

Peacemaking in the DRC", International Centre for Transitional Justice, (2009):22.

128 Ibid, 23.

129 Indonesia, Law No 27, 6 October 2004.

130 Constitutional Court of the Republic of Indonesia, Decision No 020/PUU-IV/2006. 
"in course of abiding by his/her duties or with the objective of fulfilling political motives" and had also expressed regret. ${ }^{131}$ The Commission on Investigation of Disappeared Persons, Truth and Reconciliation Act, (2014), has the authority to make recommendations for amnesty to the Government of Nepal, ${ }^{132}$ but also to make recommendations for legal action to be taken against perpetrators that are not given amnesty. ${ }^{133}$ The law does not state how the government is meant to determine whether to grant the amnesty or not. The law simply states that "If an amnesty is granted by the Government of Nepal to the person recommended by the Commission for amnesty pursuant to sub-section (1), the name of such a person shall be published in the Nepal Gazette."134

The law states that the views of the victim are supposed to be considered before a decision is taken. ${ }^{135}$ The Commission may cause "reasonable compensation" to be paid to the victim. ${ }^{136}$ The fact that the perpetrators will not receive protection against having the information they give being used against them if they are denied amnesty may be seen as a reason why potential applicants do not enter the process. They may fear that if they are not recommended for amnesty then the information they have incriminated themselves with may be used against them.

The law seems to suggest that there are limits as to when the institutions can recommend amnesty, for example, for serious offences. Nonetheless, in reality there seem to be ways around such limitations. ${ }^{137} \mathrm{Sec}-$ tion 26 (2) provides: "Notwithstanding anything contained in sub-section (1), the Commission may not make recommendation for amnesty in the case of the perpetrator who was involved in rape and who was involved in other offence of grave nature, where sufficient ground and reason are not found to grant amnesty from the investigation of the Commission." The Commission can, nevertheless, recommend amnesty if they believe there are sufficient grounds or reasons.

\footnotetext{
131 ICTJ Challenging the Conventional Can Truth Commissions Strengthen Peace Processes? 2016 76-77.

132 Article 26(1).

133 Section 13(e).

134 Article 26(8).

135 Article 26(5).

136 Section 26(7).

137 Frank Ginsbach, "The Prosecution of Human Rights Abuses in Neapal: A Himalayan Perspective on Truth and Reconciliation" Creighton International \& Comparative Law Journal, 5 (2013): 25.
}

The law determines that applicants for amnesty must make complete, written admissions of their past crimes and accept that they have committed gross violations of human rights. They must also apologise for what they have done to the victim and make a commitment not to repeat such offences. ${ }^{138}$ No protection is available to applicants if they are refused amnesty as the law determines that the information given to the Commission is to be given to other institutions and that the TC must cooperate with other bodies. ${ }^{139}$

The Supreme Court of Nepal has struck down parts of the amnesty provisions. This is because of their incompatibility with Nepali law, as well as international law, partly because the statute permits serious crimes to be amnestied. The law has not yet been redrafted. At the time of this article, the two Commissions have encountered many difficulties and have not made much progress. In part, this is because the law concerning the amnesty provisions had not been redrafted, so how it was supposed to work remains unknown. The Commissions seemingly have no policy or process to decide whom to recommend for amnesty. There is no such committee and no preliminary action to begin these proceedings. In the current structure of the TC, there is an amnesty division under its Reconciliation Unit that consists of only three staff members. However, it was vacant for a period because the government deployed these officials to oversee the electoral process. Because of this, and the lack of clarity on the process, no perpetrator has yet applied for amnesty. The Commissions are now stalling because of a lack of human, technical and financial resources, and the proposed amendments to the law have not been tabled.

In Burundi after a long period of unrest a TC was established to investigate serious human rights violations committed from 1962 to 2008. It was mandated to investigate a range of violations including killings, torture, enforced disappearances, deaths in custody and political assassinations. The amnesty task given to the Commission ${ }^{140}$ was to determine for which 'political crimes' an amnesty law could be adopted. ${ }^{141}$ The Com-

\footnotetext{
138 s. 26(3) and (4).

139 Alison Bisset, "The Privilege Against Self-Incrimination in Truth Commission-Administered Accountability Initiatives." Leiden Journal of International Law 30(1) (2017):155-176.

140 David Taylor, "We have no influence': International discourse and the Instrumentalisation of Transitional Justice in Burundi", Stability: International Journal of Security \& Development, 3(2), (2013):1-10. 141 Stef Vandeginste, "Bypassing the prohibition of amnesty for
} 
mission, while established in law, was never actually established. As a result the provision was never acted on. ${ }^{142}$ The Commission's charter contains provisions for individual amnesty procedures if it is satisfied that the applicant has made full disclosure of all relevant facts.

In Colombia, processes to grant conditional amnesties or pardons are under way as a result of the peace agreement between the Government and the FARC. ${ }^{143}$ The Peace Agreement establishes the Comprehensive System of Truth, Justice, Reparation and Non-Repetition that has five strands, including the provision of amnesty and pardon. Provided for is the Commission for the Identification of the Truth, Coexistence and Non-Repetition. ${ }^{144}$ This truth commission does not have the power to grant amnesty. ${ }^{145}$ It will have subpoena powers to get people to testify before it but the evidence it gathers may not be used in a criminal trial. The Commission has a three-year mandate to investigate and report on the violations committed during the conflict.

The power to grant conditional amnesty or pardon in Colombia is given to the Special Jurisdiction for Peace (SJP). It will also have authority to investigate, establish facts, and impose penalties. ${ }^{146}$ The SJP is comprised of a number of institutions, including a Trial Division in the event of acknowledgement of truth and responsibility, a Trial Division in the absence of acknowledgement of truth and responsibility, the Judgment Review Division, the Stability and Compliance Division and the Tribunal for Peace. The SJP can grant amnesty. However, it can also decide to waive criminal prosecutions, but the extent to which this can occur is unclear. Perpetrators, who have carried out politically associated crimes, that confess will get "special treatment" by the SJP if various verified conditions are met. The conditions to be

human rights crimes under international law: lessons learned from the Burundi peace process." Netherlands Quarterly of Human Rights 29 (2011): 189, 200.

142 Stef Vandeginste, "Burundi's Truth and Reconciliation Commission: How to shed light on the Past while Standing in the Dark Shadow of Politics?" International Journal of Transitional Justice (2012): 355-65.

143 Final Agreement to End the Conflict and Establish a Stable and Long-lasting Peace, Colombian Government.-FARC, Nov. 24, 2016.

144 Bustamante-Reyes, J. (2017). Colombia's path to peace. New Zealand International Review, 42(1), 14.

145 Ortiz Acosta, I. M. (2017). Seeking Truth in Colombia: Perspectives on a Truth Commission. Razón Crítica, 2, 21-50,

146 Due Process of Law Foundation The Special Jurisdiction for Peace in Colombia: Recommendations for the Selection of Judges of the Chambers and Divisions of the Tribunal for Peace met include providing truth to victims, acknowledging responsibility, participation in reparations programmes and provide guarantees of non-repetition. Perpetrators who confessed to their crimes will not have to serve prison time but will have their "place of residence" determined by the Peace Tribunal. ${ }^{147}$ They will also be subject to "effective restrictions on freedoms and rights" whilst performing community service. ${ }^{148}$ However what the "place of residence" will be and how much time they will have to be there each day, or what and how extensive the restrictions on their freedoms and rights will be, was not delineated in a $2017 \mathrm{draft}$ of the law. Perpetrators from the security forces will have to be resident in military units but again what this means is not stated. While the law provides that sanctions can be reduced if involvement in reparations activities occur it is not stated how this occurs or what those reductions can be. By August 2017 1,502 state security officials and 2,817 FARC fighters had indicated that they wanted to go through the SJP process. ${ }^{149}$ How the process will work and what its effects and outcomes will be remain to be determined.

Thus a number of other processes have been established that affect the role that truth commissions play concerning amnesty. Some of them never came to fruition and some of them are still in formation today so how they will work and what the role of the TC will be is unclear.

\section{Conclusion}

The use and extent of TC amnesties around the world show that they continue to be a popular tool. They have an enormous number of roles. They can play important functions in transitional societies. They can have the effect of stopping a conflict if all parties accept and buy into such an arrangement. While amnesties are usually viewed as problematic, they can have beneficial effects. Amnesties can play a symbiotic role with and be beneficial to TCs in their truth recovery

147 Proyecto de ley Estatutaria de la Administración de Justicia en la Jurisdicción Especial para la Paz), bill no. 8/2017.

148 Josi, Claudia. «Accountability in the Colombian Peace Agreement: Are the Proposed Sanctions Contrary to Colombia's International Obligations.» Southwestern Law. Review. 46 (2016): 401.

149 El Espectador: Las incógnitas de la Justicia Especial para la Paz, 22 August 2017 
processes. However, this is dependent on the way the amnesty process is structured to begin with, and the way it is carried out.

Giving perpetrators amnesty can be beneficial for truth recovery processes because these persons have much to reveal about the events that occurred. However, perpetrators do not usually participate in the processes of search for truth out of fear that the weight of the law will be brought against them. They are usually not willing to participate in the proceedings if they do not obtain guarantees of protection against being prosecuted. Thus, tools such as amnesties can be very useful for truth-seeking processes. Truth commissions largely take into account the narratives of the testimony of the victims, without taking into account the voices of other actors involved in the conflict. ${ }^{150}$ However, victims do not have many specific facts to tell when it comes to events that occurred outside the specific situation in which they were involved. Instead, learning from direct testimonies given by perpetrators would clarify many more situations. For example, past offenders could reveal who ordered, organised, was involved, prepared, and executed certain abuses. Usually, these matters remain unknown or only known to a very limited extent and then, to very few people.

All the TC processes recommending amnesty discussed in this article including Grenada, Indonesia, the Democratic Republic of the Congo (DRC), Nepal, in the joint Timor-Leste/Indonesia process, Liberia, Kenya, and Korea, but not in the sole Timor-Leste model, show the problems in having a process where a TC simply recommends amnesty. These models, besides the Timor-Leste process (for its own contextual reasons), show that few perpetrators trust these processes enough to come forward in any numbers. They seemingly will not engage in a process in which an institution only recommends amnesty. It seems as though a greater degree of certainty is needed for them to testify and provide information about their crimes without some protection against criminal or civil liability.

Thus, when TCs are given the power to grant amnesty they seem to attract more applicants. The reason being that in this case, there is only one level of ad-

150 N. V. Nwogu, "When and Why it Started: Deconstructing Victim-Centered Truth Commissions in the Context of Ethnicity-Based Conflict", International Journal of Transitional Justice, 4 (2010):275. ministrator to convince, not two. Also it is presumed that TCs will exercise their decision making in a less political, more partisan way. When it comes to TCs recommending amnesty the overall position seems to be that this methodology seems not to inspire confidence from would-be applicants. They seem to shy away from a two-step process (TC and then government decision) that sees a final decision being taken by political actors. The South African experience also seems to indicate that where there are judges involved. and that if some of them come from same group as the perpetrators there will be greater trust in the process.

Thus, a truth commission process that grants amnesty rather than recommending amnesty seems preferable. It is more likely to achieve the result that perpetrators will engage with the truth recovery process. It is however quite context specific and depends on how it is established, how complex it is, whether perpetrators trust the system and whether they believe they need amnesty. Perpetrators will, before deciding whether to enter a conditional amnesty, weigh up whether they need amnesty and whether there is likelihood that they will be prosecuted if they do not apply. Thus, conditional amnesties will work if the state shows that it has the will and ability to carry out such prosecutions.

If the state is not willing to grant amnesty it may be useful to grant the institution doing the truth recovery the powers to grant use immunity. If use immunity is given to disclosures which are provided to a TC, this would induce more people to divulge information. ${ }^{151}$ While the value of these immunities can be questioned, as prosecutors would know about the crimes committed and can look for evidence elsewhere, the level of protection might still be sufficient for perpetrators to come forward.

\section{BiBLIOGRAPHY}

Allan, Kate. «Prosecution and Peace: A Role for Amnesty before the ICC.» Denver Journal of International Law and Policy 39 (2010): 239 - 242.

Amnesty International Public Statement. AI Index:

151 Alison Bisset, "The Privilege Against Self-Incrimination in Truth Commission-Administered Accountability Initiatives.” Leiden Journal of International Law 30.1 (2017): 173. 
AFR 34/010/2008. Liberia: Will those investigated by the Truth and Reconciliation Commission ever be prosecuted? PDF. Liberia: TRCL, 2008. https: / / www.amnesty.org/download/Documents/52000/afr340102008en.pdf

Asaala, Evelyne. «Exploring Transitional Justice as a Vehicle for Social and Political Transformation in Kenya.» African Human Rights Law Journal 10, no. 2 (2010): 377-406.

Baik, Tae-Ung. «Fairness in Transitional Justice Initiatives: The Case of South Korea.» Buffalo Human Rights Law Review 19 (2012): 169-273

Bhargava, Rajeev. «Restoring Decency To Barbaric Societies». In Truth Versus Justice: The Morality Of Truth Commissions, edited by Robert I. Rotberg and Dennis Thompson, 45-67. New Jersey: Princeton University Press, 2000.

Bisset, Alison. 'Principle 9: Guarantees for Persons Implicated', in The United Nations Principles to Combat Impunity: A Commentary, edited by Frank Haldemann and Thomas Unger. Oxford: Oxford University Press, 2017.

Bisset, Alison. «The Privilege Against Self-Incrimination in Truth Commission-Administered Accountability Initiatives.» Leiden Journal of International Law 30, no. 1 (2017): 155-176.

Borer, Tristan Anne. Truth Telling As A Peace-Building Activity: A Theoretical Overview. Notre Dame, Indiana: University of Notre Dame Press, 2006.

Burgess, Patrick and Galuh, Wandita. "Reaching Out to Victims and Communities: The CAVR's Experiences in Timor-Leste," in Transitional justice, culture, and society: Beyond outreach, edited by Clara Ramirez-Barat, 141-172. Social Science Research Council, 2014.

Burgess, Patrick. «East Timor's Community Reconciliation Process». In Transitional justice in the twenty-first century: Beyond truth versus justice, edited by Roht-Arriaza, Naomi, and Javier Mariezcurrena, 176-205. Cambridge University Press, 2006.

Burgess, Patrick. "Justice and Reconciliation in East Timor. The Relationship between the Commission for Reception, Truth and Reconciliation and the Courts.» In Truth Commissions And Courts, edited by William Schabas and Shane Darcy, 135-158. Springer Netherlands, 2004.

Bustamante-Reyes, Juliana. «Colombia's Path to Peace.» New Zealand International Review 42, no. 1 (2017):
$14-17$.

Byung-Ook, Ahn. President of the Republic of Korea. Truth and Reconciliation Activities of the Past Three Years. PDF. Republic of Korea: TRC, 2009. https://www.usip. org/sites/default/files/ROL/South_Korea_2005_reportEnglish.pdf

Childers, Jacob. «Amnesty, Revenge, and the Threat of Conflict Relapse.»International Criminal Law Review 14, no. 6 (2014): 1095-1122.

Clark, Janine Natalya. «Transitional Justice, Truth and Reconciliation: an Under-explored Relationship.» International Criminal Law Review 11, no. 2 (2011): 241-261.

Cobban, Helena. «Amnesty After Atrocity.» Healing nations after genocide and war crimes. Boulder, Colorado: Paradigm, 2007.

Colombia, El Congreso de Colombia. Proyecto de ley Estatutaria de la Administración de Justicia en la Jurisdicción Especial para la Paz. PDF. Colombia: Las incógnitas de la Justicia Especial para la Paz, 2017. http://dacn. mininterior.gov.co/sites/default/files/noticias/proyecto_de_ley_estatutaria_de_la_administracion_de_justicia_en_la_jurisdiccion_especial_para_la_paz.pdf

Colombia. Final Agreement to End the Conflict and Establish a Stable and Long-lasting Peace. Colombia: FARC, 2016.

Constitutional Court of the Republic of Indonesia. Decision No 020/PUU-IV/2006:

Challenging the Conventional Can Truth Commissions Strengthen Peace Processes? Indonesia: ICTJ, 2016.

Dancy, Geoff, Hunjoon Kim, and Eric WiebelhausBrahm. «The Turn to Truth: Trends in Truth Commission Experimentation.» Journal of Human Rights 9, no. 1 (2010): 45-64.

Davis, Laura, and Priscilla Hayner. «Difficult Peace, Limited Justice: Ten years of Peacemaking in the DRC.» International Centre for Transitional Justice 36 (2009) $1-39$.

Dong-Choon, Kim. «Korea's Truth and Reconciliation Commission: An Overview and Assessment.» Buffalo Human Rights Law Review 19 (2012): 97-273

Fiddler, Grace. «Using a Conditional Amnesty and Truth and Reconciliation Commission as a Transitional Justice Mechanism in Syria.» The George Washington Institute of International Law Review 47 (2015): 893-918. 
Freeman, Mark. Necessary Evils: Amnesties and the Search for Justice. Cambridge University Press, 2009.

Ginsbach, Frank. "The Prosecution of Human Rights Abuses in Neapal: A Himalayan Perspective on Truth and Reconciliation" Creighton International \& Comparative Law Journal 5 (2013): 1-50.

Gitau, Rosalia de la Cruz. «'God willing, I will be back’: Gauging the Truth and Reconciliation Commission's Capacity to Deter Economic Crimes in Liberia.» African Security Review 17, no. 4 (2008): 64-78.

Grenada, Truth and Reconciliation Commission of Grenada. Report on Certain Political Events which Occurred between 1976-1991, Grenada. 2006. https://www.thegrenadarevolutiononline.com/trccontents.html

Hayner, Priscilla B. Negotiating Peace In Liberia. Geneva: HD Centre for Humanitarian Dialogue, 2007.

Hayner, Priscilla B. Unspeakable Truths 2e: Transitional Justice and the Challenge of Truth Commissions. Routledge, 2010.

James-Allen, Paul, Aaron Weah, and Lizzie Goodfriend. Beyond the Truth and Reconciliation Commission: Transitional Justice Options in Liberia. New York and Monrovia: International Center for Transitional Justice (ICTJ), 2010.

Järvinen, Taina. Human rights and post-conflict transitional justice in East Timor. Finnish Institute of International Affairs, 2004.

Jeffery, Renée. "Trading Amnesty for Impunity in Timor-Leste.» Conflict, Security \& Development 16 no. 1 (2016): 33-51.

Josi, Claudia. «Accountability in the Colombian Peace Agreement: Are the Proposed Sanctions Contrary to Colombia's International Obligations.» Southwestern Law Review 46 (2016): 401-422.

Julie A. Keil, "Liberia's TC: The Road to Rule of Law or a Dead End?." African Journal of Political Science and International Relations 11, no. 8 (2017): 201-209.

Kambala, Olivier and Tyrone Savage. «Decayed, Decimated, Usurped and Inadequate: The Challenge of Finding Justice through Formal Mechanisms in the Democratic Republic of Congo.» In Restoring Justice after Large-scale Violent Conflicts, edited by Ivo Aersten et al. 336-358. New York: Willan Publishing, 2008.

Katzenstein, Suzanne. «Hybrid Tribunals: Searching for Justice in East Timor.» Harvard Human Rights Journal 16
(2003): 245-278

Kenya, The Truth, Justice and Reconciliation Act 6 of 2008, Kenya. Nairobi: KLR, 2008.

Kenya, Truth, Justice and Reconciliation Commission of Kenya. Final Report of the Truth, Justice and Reconciliation Commission, Kenya. PDF. Nairobi: TJRC Kenya, 2013. http://knchr.org/Portals/0/Reports/TJRC_Volume_4.pdf

Korea, Parliament of Korea. "Framework Act on Clearing up Past Incidents for Truth and Reconciliation, Enacted by Law No. 7542." PDF. Parliament of Korea, 2005. https://www.usip.org/sites/default/files/ROL/ Framework_Act.pdf

Krueger, Anne K. «The Global Diffusion of Truth Commissions: an Integrative Approach to Diffusion as a Process of Collective Learning.» Theory and Society 45, no. 2 (2016): 143-168.

La République Démocratique du Congo, La Commissiopn Verite et Reconciliation. Loi No. /04/018 du Juillet 302004 portant sur l'organisation. PDF. La République Démocratique du Congo: CVR, 2004.

http:/ /www.icla.up.ac.za/images/un/commissionsofinquiries / files/DRC $\% 202003 \% 20$ commission $\% 20$ -\%20TORs.pdf

La République Démocratique du Congo. Constitution de la transition de la République démocratique du Congo. 2003. https://www.droitcongolais.info/files/106_constitution_de_la_transition_de_la_rdc_dav.pdf

Langer, Johannes. 2017. «Are Truth Commissions Just Hot-Air Balloons? A Reality Check On The Impact Of Truth Commission Recommendations». Desafíos 29 (1): $177-210$.

Lessa, Francesca, and Leigh A. Payne, eds. Amnesty in the Age of Human Rights Accountability: Comparative and International Perspectives. Cambridge University Press, 2012.

Lessa, Francesca, Tricia D. Olsen, Leigh A. Payne, Gabriel Pereira, and Andrew G. Reiter. «Persistent or Eroding Impunity? The Divergent Effects of Legal Challenges to Amnesty Laws for Past Human Rights Violations.» Israel Law Review 47, no. 1 (2014): 105-131.

Liberia, Ministry of Foreign Affairs. «Liberia: An Act to Establish the Truth and Reconciliation Commission (TRC) of Liberia 2005.» Refworld. 2005. http://www. refworld.org/docid/473c6b3d2.html. 
Loyle, Cyanne E., and Christian Davenport. «Transitional injustice: Subverting justice in transition and postconflict societies.» Journal of Human Rights 15, no. 1 (2016): 126-149.

Lundy, Patricia. «Commissioning the Past in Northern Ireland.» Review of International Affairs 60, no. 1138-1 (2010): 101-133.

Mallinder, Louise. «Amnesties' Challenge To The Accountability Norm». In Amnesty In The Age Of Human Rights Accountability: Comparative And International Perspectives, edited by Francesca Lessa and Leigh A. Payne, 6996. Cambridge: Cambridge University Press, 2012.

Mallinder, Louise. Amnesty, Human Rights and Political Transitions: Bridging the Peace and Justice Divide. Bloomsbury Publishing, 2008.

McAuliffe, Padraig. «East Timor's Community Reconciliation Process as a Model for Legal Pluralism in Criminal Justice'.» Law, Social Justice \& Global Development 2 (2008).

Melish, Tara J. «Implementing Truth and Reconciliation: Comparative Lessons for the Republic of Korea.» Buffalo Human Rights law Review 19 (2012): 1-273

Mendlloff, David. «Truth-Seeking, Truth-Telling, And Post-Conflict Peacebuilding: Curb The Enthusiasm?». International Studies Review 6, no. 3 (2004): 355-380.

Minow, Martha. «Making History or Making Peace: When Prosecutions Should Give Way to Truth Commissions and Peace Negotiations.» Journal of Human Rights 7, no. 2 (2008): 174-185.

Moon, Claire. Narrating Political Reconciliation: South Africa's Truth and Reconciliation Commission. Lexington Books, 2008.

Naftali, Patricia. "Crafting a "Right to Truth" in International Law: Converging Mobilizations, Diverging Agendas?.» Champ pénal/ Penal field 13 (2016).

Neier, Aryeh. War crimes: Brutality, Genocide, Terror, and the Struggle for Justice. New York: Crown Publishing Group, 1998.

Nesiah, Vasuki. «Transitional Justice Practice: Looking Back, Moving Forward.» Impunity Watch, 2016.

Nwogu, Nneoma V. «When and Why it Started: Deconstructing Victim-centered Truth Commissions in the Context of Ethnicity-based Conflict.» International Journal of Transitional Justice 4, no. 2 (2010): 275-289.
Ojielo, Ozonnia. «Critical Lessons in Post-Conflict Security in Africa: The case of Liberia's Truth and Reconciliation Commission.» Institute for Justice and Reconciliation, 2010.

Olsen, Tricia D, Leigh A Payne, and Andrew G Reiter. Transitional Justice In Balance: Comparing Processes, Weighing Efficacy. Washington, United States: Institute of Peace Press, 2010.

Olsen, Tricia D., Leigh A. Payne, Andrew G. Reiter, and Eric Wiebelhaus-Brahm. «When Truth Commissions Improve Human Rights.» International Journal of Transitional Justice 4, no. 3 (2010): 457-476.

Ortiz Acosta, Ingrid Marisol. «Seeking Truth in Colombia: Perspectives on a Truth Commission.» Razón Crítica 2 (2017):21-50.

Pajibo, Ezekiel. «Civil Society and Transitional Justice in Liberia: A Practitioner's Reflection from the Field.» The International Journal of Transitional Justice 1, no. 2 (2007): 287-296.

Pierce, Natalie. «Picking up the Pieces: Truth and Justice in Sierra Leone.» New Zealand Journal of Public and International Law 6, no. 2 (2008): 117-156.

Pigou, Piers. «Degrees of Truth: Amnesty and Limitations in the Truth Recovery Project.» The Provocations of Amnesty: Memory, Justice and Impunity (2003): 217-236.

Pigou, Piers. «The Community Reconciliation Process of the Commission for Reception, Truth and Reconciliation.» United Nations Development Programme TimorLeste (2004).

Popkin, Margaret. Peace Without Justice: Obstacles to Building the Rule of Law in El Salvador. Penn State Press, 2000.

Sarkin, Jeremy, «Achieving Reconciliation in Divided Societies.» Yale Journal of International Affairs 3, no.2 (2008): 11-28.

Sarkin, Jeremy, "An Evaluation of the South African Amnesty Process" In Truth and reconciliation in South Africa: Did the TRC deliver? Edited by Hugo Van der Merwe, and Audrey R. Chapman, 93-115. University of Pennsylvania Press, 2008.

Sarkin, Jeremy, «Dealing with Enforced Disappearances in South Africa (With a Focus on the Nokuthula Simelane Case) and Around the World. The Need to Ensure Progress on the Rights to Truth, Justice and Reparations in Practice.» Speculum Juris Volume 29 (2015): 20-48. 
Sarkin, Jeremy, «The Development of a Human Rights Culture in South Africa.» Human Rights Quarterly 20, no. 3 (1998): 628-665.

Sarkin, Jeremy, «Understanding the Journey to Reconciliation in Transitional Societies: Using the Metaphor of a Motor Vehicle Road Trip to Understand South Africa's Path (Process) to Political Reconciliation.» International Journal of African Renaissance Studies-Multi-, Inter-and Transdisciplinarity 10, no. 2 (2015): 87-103.

Sarkin, Jeremy, and Tetevi Davi. «Examining The Criticisms Levelled Against Transitional Justice: Towards An Understanding Of The State Of The Field». Human Rights And International Legal Discourse 11, no. 1 (2017): 7-22.

Sarkin, Jeremy, and Tetevi Davi. «The Togolese Truth, Justice and Reconciliation Commission: Lessons for Transitional Justice Processes Elsewhere.» Peace and Confict Studies 24, no. 1 (2017): 1-27.

South Africa, Parliament. "Promotion of National Unity and Reconciliation Act, 1995 (South Africa)." Journal of African Law 39, no. 2 (1995): 231-231.

Slye, Ronald C. "Putting the J into the TC: Kenya's Truth Commission: Forthcoming in Twenty Years On: Other Ways of Being and the South African Truth Reconciliation Commission", Seattle University School of Law Research Paper 17, no.8 (2017): 26.

Taylor, David. "We have no influence': International Discourse and the Instrumentalisation of Transitional Justice in Burundi", Stability: International Journal of Security \& Development 3, no. 2 (2013):1-10.

Teitel, Ruti. «The Law and Politics of Contemporary Transitional Justice.» Cornell International Law Journal 38, no.3 (2005): 837-62

Timor-Leste, Commission for Reception, Truth and Reconciliation. "Community Reconciliation." In Chega! Final Report of the Commission for Reception, Truth and Reconciliation in East Timor. PDF. CAVR, 2005. http://
www.etan.org/etanpdf/2006/CAVR/09-CommunityReconciliation.pdf

United Nations Transitional Administration in East Timor. Regulation No. 2001/10. East Timor: UNTAET, 2001.

United Nations, Office of the United Nations High Commissioner for Human Rights. Rule-of-Law Tools for Post-Conflict States: Truth Commissions. Geneva: UN, 2006.

Vandeginste, Stef. «Burundi's Truth and Reconciliation Commission: How to shed light on the Past while Standing in the Dark Shadow of Politics?.» International Journal of Transitional Justice 6, no. 2 (2012): 355-365.

Vandeginste, Stef. «Bypassing the Prohibition of Amnesty for Human Rights Crimes under International Law: Lessons Learned from the Burundi Peace Process.» $\mathrm{Ne}$ therlands Quarterly of Human Rights 29, no. 2 (2011): 189211.

Varney, Howard, and Jeremy Sarkin. «Failing to pierce the hit squad veil: An analysis of the Malan trial.» South African Journal of Criminal Justice 10 (1997): 141.

Weah, Aaron. «Hopes and Uncertainties: Liberia's Journey to end Impunity.» International Journal of Transitional Justice 6, no. 2 (2012): 331-343.

Weissbrodt, David. "Review Of Andreas O'Shea, Amnesty For Crime In International Law And Practice" American Journal of International Law 97 (2003): 227.

Wilson, Richard. The Politics of Truth and Reconciliation in South Africa: Legitimizing the Post-Apartheid State. Cambridge University Press, 2001.

Wolman, Andrew. «Looking Back While Moving Forward: The Evolution of Truth Commissions in Korea.» Asian-Pacific Law and Policy Journal 14 (2012): 27-56.

Zifcak, Spencer. «Restorative Justice in East Timor: An Evaluation of the Community Reconciliation Process of the Truth and Reconciliation Commission of East Timor.» New York: The Asia Foundation, 2004. 
Para publicar na Revista de Direito Internacional, acesse o endereço eletrônico www.rdi.uniceub.br ou www.brazilianjournal.org.

Observe as normas de publicação, para facilitar e agilizar o trabalho de edição. 